Der Einfluss des Eisenstoffwechsels und die Rolle der peripheren nervalen Inflammation in der Entwicklung der peripheren Neuropathie bei adipösen nichtdiabetischen leptindefizienten $o b / o b$-Mäusen

\author{
Dissertation \\ zur Erlangung des akademischen Grades
}

Dr.med.

an der Medizinischen Fakultät

der Universität Leipzig

eingereicht von: Katrin Woidt

Geburtsdatum/Geburtsort: $\quad 01.04 .1986$ in Görlitz

angefertigt an/in: Universität Leipzig/Institut für Anatomie

Betreuer: $\quad$ PD Dr. Marcin Nowicki

Beschluss über die Verleihung des Doktorgrades vom: 17.11.2020 


\section{Inhaltsverzeichnis}

$\begin{array}{ll}\text { Abkürzungsverzeichnis } & 3\end{array}$

1. Einleitung 4

1.1. Adipositas 4

1.2. Metabolisches Syndrom 5

$\begin{array}{ll}\text { 1.3. Periphere Neuropathie } & 7\end{array}$

1.4. Eisen 9

1.4.1. Eisen und Adipositas 9

1.4.2. Eisen und oxidativer Stress $\quad 12$

1.4.3. Eisen und neurodegenerative Erkrankungen 13

2. Ziel der Arbeit 15

3. Material/Methoden 16

4. Publikation 19

5. Zusammenfassung 32

6. Literaturverzeichnis 35

7. Anhang 43

7.1. Tabellenverzeichnis 43

7.2. Abbildungsverzeichnis 43

8. Darstellung des eigenen Beitrags 44

9. Erklärung über die eigene Abfassung der Arbeit 45

10. Lebenslauf 46

11. Danksagung 48 


\section{Abkürzungsverzeichnis}

$\begin{array}{ll}\text { Abb. } & \text { Abbildung } \\ \text { bzw. } & \text { beziehungsweise } \\ \text { BMI } & \text { Body-Mass-Index }\left(\mathrm{BMI}=\mathrm{m}(\mathrm{kg}) / \mathrm{l}(\mathrm{m})^{2}\right) \\ \mathrm{CD} & \text { Cluster of Differentiation } \\ \mathrm{CRP} & \text { C- reaktives Protein } \\ \text { DEGS } & \text { Studie zur Gesundheit der Erwachsenen in Deutschland } \\ \text { DGAV } & \text { Deutschen Gesellschaft für Allgemein- und Viszeralchirurgie e.V. } \\ \text { DMII } & \text { Diabetes mellitus Typ II } \\ \text { DMT } & \text { divalent metal transporter 1 } \\ \text { DNA } & \text { desoxyribonucleic acid } \\ \text { et al. } & \text { und andere } \\ \text { etc. } & \text { und weitere } \\ \text { ER } & \text { endoplasmatisches Retikulum } \\ \text { Fe } 2^{+} & \text {zweiwertiges Eisen } \\ \text { Fe } 3^{+} & \text {dreiwertiges Eisen } \\ \text { FPN } & \text { Ferroportin 1 } \\ \text { g/kg } & \text { Gramm/Kilogramm } \\ \mathrm{H} & \text { Hephästin } \\ \mathrm{HDL} & \text { high density lipoprotein } \\ \mathrm{H}_{2} \mathrm{O}_{2} & \text { Wasserstoffperoxid } \\ \mathrm{HCP} & \text { heme carrier transporter 1 } \\ \mathrm{IDF} & \text { International Diabetes Federation } \\ \mathrm{IFB} & \text { Integriertes Forschungs- und Behandlungszentrum } \\ \mathrm{IL}-6 & \text { Interleukin 6 } \\ \text { LDL } & \text { low density lipoprotein } \\ \mathrm{MetS} & \text { Metabolisches Syndrom } \\ \mathrm{MP} & \text { Morbus Parkinson } \\ \mathrm{NE} & \text { neurodegenerative Erkrankungen } \\ \mathrm{O}_{2} & \text { Sauerstoff } \\ \text { RES } & \text { retikuloendotheliales System } \\ \mathrm{RLS} & \text { Restless-Legs-Syndrom } \\ \text { ROS } & \text { reactive oxygen species } \\ \mathrm{STZ} & \text { Streptotozotin } \\ \mathrm{TNF}-\alpha & \text { Tumornekrosefaktor alpha } \\ \text { Tf } & \text { Transferrin } \\ \text { TfR } & \text { Transferrinrezeptor 1 } \\ \mathrm{WHO} & \text { World Health Organisation } \\ \text { ZCB } & \text { Zytochrom B } \\ \text { ZNS } & \text { Zentrales Nervensystem } \\ & \end{array}$




\section{Einleitung}

\subsection{Adipositas}

Adipositas zählt aktuell zu den Erkrankungen, die sich weltweit, vor allem in den Industrieländern, explosionsartig verbreiten.

Übergewicht besteht ab einem Body-Mass-Index (BMI) $>25 \mathrm{~kg} / \mathrm{m}^{2}$. Ab einem BMI > 30 $\mathrm{kg} / \mathrm{m}^{2}$ wird die Bezeichnung Adipositas verwendet. Dazwischen gibt es Präadipositas mit einem BMI, der zwischen 25 - 29,9 kg/m² liegt. Ab einer Adipositas-Grad III bei einem BMI $>40 \mathrm{~kg} / \mathrm{m}^{2}$ - besteht eine Adipositas permagna. Laut Weltgesundheitsorganisation (WHO) waren 2017 mehr als 1,9 Milliarden Erwachsene übergewichtig, davon waren über 650 Millionen adipös. Das entspricht einem Anteil von $13 \%$ der Weltbevölkerung. Mit steigendem BMI wächst das Risiko für das Auftreten von Komorbiditäten. Dazu zählen unter anderem kardiovaskuläre Erkrankungen, Diabetes mellitus vom Typ 2 (DMII), muskuloskelettale Erkrankungen oder einige Tumorarten (WHO, 2000 und 2017).

Eine Auswertung der Studie zur Gesundheit der Erwachsenen in Deutschland (DEGS) wies im Zeitraum von 1990 bis 2011 auf eine steigende Adipositasprävalenz in Deutschland hin (Mensink et al., 2013). Es kam vor allem in der Altersgruppe der 25- bis 34-Jährigen, sowohl bei den Frauen als auch bei den Männern zu einem starken Anstieg innerhalb dieses Zeitraums (Männer: $6 \%$, Frauen: $5 \%$ ). Es ist besorgniserregend, wie rasant sich Adipositas weltweit in allen Altersklassen ausbreitet (Mensink et al., 2013).

Adipositas ist eines der wichtigsten Gesundheitsprobleme unserer Neuzeit. Es stellt mittlerweile ein eigenes Themengebiet dar, das in jeglichen Bereichen von steigendem Interesse ist. Gynäkologie und Fertilisationsmedizin setzen sich mit dem Zusammenhang zwischen Adipositas und Infertilität auseinander. Die Psychologie und Psychiatrie beschäftigen sich unter anderem mit der psychischen Belastung vor und nach dem Auftreten der Adipositas. Auch die Neurologie ist ein weiterer Medizinbereich, der sich mit den durch Adipositas bzw. durch das metabolische Syndrom (MetS) bedingten Komplikationen befasst, unter anderem der Neuropathie. Außerdem werden in der bariatrischen Chirurgie ästhetische Aspekte und die sekundären Folgen von Operationen bei Adipositaspatienten betrachtet. (Birkmeyer et al., 2013; Dağ et Dilbaz, 2015; Herpertz et Saller, 2001; O`Brien et al. 2017).

Das Errichten von Spezialzentren und eine Zunahme an Forschungsgruppen, die sich primär auf Adipositas und deren Komorbiditäten fokussieren, machen den maßgeblichen Einfluss der Übergewichtigkeit auf unseren Gesundheitszustand in der heutigen Zeit deutlich (Deutsche Gesellschaft für Allgemein- und Viszeralchirurgie e.V. DGAV; Kompetenznetz- Adipositas; 
Integriertes Forschungs- und Behandlungszentrum (IFB) AdipositasErkrankungen Universitätsklinikum Leipzig).

\subsection{Metabolisches Syndrom}

Adipositas ist mit weiteren Erkrankungen assoziiert. Übergewicht stellt einen wesentlichen Risikofaktor des MetS dar. Geprägt wurde die Bezeichnung 1981 von Hanefeld und Leonhardt (Hanefeld et al., 1981). Studien konnten zeigen, dass mehrere Einflüsse für die Entstehung des MetS verantwortlich sind. $\mathrm{Zu}$ den Risikofaktoren zählen eine genetische Veranlagung, ein gesundheitsgefährdender Lebensstil, bestimmte Ernährungsgewohnheiten sowie bestimmte psychosoziale Faktoren.

Das MetS ist der Sammelbegriff für das Vorliegen eines gestörten Fettstoffwechsels, wobei Triglyceride erhöht und HDL (high density lipoprotein) vermindert sind. Hierzu gehören ebenfalls stammbetonte Adipositas, Insulinresistenz (Diabetes oder Prädiabetes) und Bluthochdruck. Die Diagnose des MetS wird nach Vorliegen von mindestens drei der folgenden fünf Kriterien gestellt: Abdominale Adipositas (Taillenumfang > $94 \mathrm{~cm}$ bei Männern, > $80 \mathrm{~cm}$ bei Frauen), Nüchtern-Triglyceride über $150 \mathrm{mg} / \mathrm{dl}$, verminderte HDLFraktion ( $<50 \mathrm{mg} / \mathrm{dl}$ bei Frauen und $<40 \mathrm{mg} / \mathrm{dl}$ bei Männern), systemarterieller Blutdruck über systolisch $130 \mathrm{mmHg}$ oder diastolisch $85 \mathrm{mmHg}$ und ein Nüchternblutzucker über 100 mg/dl (Alberti et al., 2005; IDF 2005).

Das MetS ist ein inflammatorischer Zustand, der auf verschiedenste Stoffwechselvorgänge im Körper Einfluss nimmt (Monteiro et Azevedo, 2010; Saltiel et Olefsky, 2017; Wisse, 2004). Besonders im Hinblick auf das Immunsystem stellt die Inflammation in weißem Fettgewebe einen entscheidenden Faktor bei der Entstehung pathologischer Merkmale des MetS, vor allem des DMII und der Arteriosklerose, dar (Trayhurn et Wood, 2004; Wisse, 2004). Adipozyten bedingen Reaktionen, die zu einer chronisch latenten Entzündungsreaktion im Fett und somit $\mathrm{zu}$ einem proinflammatorischen Zustand führen. Als Ursache werden Hypoxie, Aktivierung von Stresssignalen im endoplasmatischen Retikulum, sowie oxidativer Stress vermutet (Houstis et al., 2006; Kawasaki et al., 2012; Ozcan et al., 2004; Trayhurn et Wood, 2004). Oxidativer Stress ist die Reaktion der Mitochondrien, riesige Mengen überschüssiger Nahrung zu verstoffwechseln. Im Fettgewebe kann oxidativer Stress durch die Migration von Makrophagen die Bildung proinflammatorischer Zytokine aktivieren, z.B. Tumornekrosefaktor- $\alpha$ (TNF- $\alpha$ ), Leptin und Interleukin-6 (IL-6). Proinflammatorische Kaskaden werden dadurch in Gang gesetzt (Stafeev et al., 2015; Trayhurn et Wood, 2004). 
Zusätzlich produzieren Adipozyten selbst Zytokine und Hormone wie Adiponektin oder Leptin, die einen Inflammationsprozess additiv forcieren (Carrillo et al., 2018).

Studien konnten belegen, dass mit zunehmender Adipositas die Konzentration des durch Adipozyten sezernierten IL-6 steigt. Die im Serum gemessene IL-6- Konzentration, sowie die Konzentration an TNF- $\alpha$, Leptin und C-reaktives Protein (CRP) korreliert eng mit dem Körperfettanteil. Diese Inflammationsmarker waren bei adipösen diabetischen und nichtdiabetischen Frauen signifikant höher als bei gesunden Frauen (Tabelle 1).

Tab.1 Vergleich der Serumkonzentrationen von IL-6, TNF- $\alpha$ und CRP adipöser diabetischer (Alter: 51-66 Jahre, BMI: 29- 39,6 kg/m²), adipöser nichtdiabetischer (Alter: 28- 64 Jahre, BMI: 32,9- 48,7 kg/m²) und gesunder Frauen (Alter: 24- 69 Jahre, BMI: 18,4- 23,2 kg/m²), Bastard JP et al., 2000.

\begin{tabular}{|l|l|l|l|}
\hline & Vergleichsgruppe $(\mathrm{n}=8)$ & $\begin{array}{l}\text { adipös, kein } \\
\text { Diabetes }(\mathrm{n}=14)\end{array}$ & $\begin{array}{l}\text { adipös, Diabetes } \\
(\mathrm{n}=7)\end{array}$ \\
\hline IL-6 $(\mathrm{pg} / \mathrm{ml})$ & $0,39-+0,06$ & $2,78-+0,3$ & $3,58-+0,51$ \\
\hline TNF- $\alpha(\mathrm{pg} / \mathrm{ml})$ & $0,74-+0,09$ & $1,48-+0,15$ & $1,08-+0,12$ \\
\hline $\mathrm{CRP}(\mathrm{ml} / \mathrm{L})$ & $1,2-+0,3$ & $6,3-+1,1$ & $5,8-+1,1$ \\
\hline
\end{tabular}

TNF- $\alpha$ ist ein Zytokin, welches von Makrophagen bzw. Monozyten im Rahmen einer akuten Entzündungsreaktion produziert wird. Es ist für eine Reihe von Signalkaskaden in den Zellen verantwortlich, die zu Nekrose oder Apoptose führen (Idriss et Naismith, 2000). Eine Studie um Mohammadi et al. (2017) konnte den Zusammenhang, vor allem zwischen den proinflammatorischen Parametern TNF- $\alpha$ und IL-6 mit dem MetS aufzeigen. Bei Patienten mit MetS konnten im Vergleich zu gesunden Probanden erhöhte Serumkonzentrationen an TNF- $\alpha$ und IL-6 nachgewiesen werden (Mohammadi et al., 2017).

In einer weiteren Studie, die diese Ergebnisse belegen konnte, wurden zusätzlich antiinflammatorische Zytokine betrachtet, die beim Vorliegen des MetS vermindert waren. Basierend auf diesen Ergebnissen ist es perspektivisch möglich, proinflammatorische Parameter wie TNF- $\alpha$ und IL-6 als Biomarker für die Diagnose, Prognose und Therapieansätze des MetS zu verwenden (Srikanthan et al., 2016).

Ein weiterer hier erwähnter Inflammationsparameter ist das CRP. Es gehört zu den Pentraxinen, welche in der Leber gebildet und in das Blut sezerniert werden. Es zählt zu der 
Gruppe der Akute-Phase-Proteine und wird genauso wie das TNF- $\alpha$ als ein wichtiger Marker des metabolischen Risikos gesehen. Einige Autoren beschreiben das CRP als anerkannten Prädiktor für das kardiovaskuläre Erkrankungsrisiko (Sattar et al., 2003; Szmitko et al., 2007). Unabhängige Studien belegen, dass bei dem Vorliegen von Typ-2-Diabetes (DMII) mit steigenden Risikofaktoren des MetS mehr Komplikationen des DMII auftraten. Dies gilt vor allem für periphere Gefäßerkrankungen, diabetische Retinopathie, Neuropathie, Mikro- und Makroalbuminurie sowie koronare Herzerkrankungen (Costa et al., 2004; Isomaa ${ }^{1}$ et al., 2001).

\subsection{Periphere Neuropathie}

Die peripheren Neuropathien werden durch Schädigung motorischer, sensibler oder autonomer Neuronen und Nervenfasern verursacht. Sie zählen zu den chronischen irreversiblen Erkrankungen. Derzeit sind etwa 500 Ursachen der peripheren Neuropathie bekannt. Die Prävalenz wird auf 2,4\% in der Bevölkerung und bis zu $8 \%$ bei Patienten über 55 Jahren geschätzt (Baldereschi et al 2007; Martyn et al., 1997).

Die diabetische Neuropathie ist die häufigste periphere Polyneuropathie in Europa (Feldman et al., 2017). Daneben gibt es immunvermittelte (Guillan-Barré-Syndrom), toxische (Alkohol, Benzol, Chemotherapeutika, Schwermetalle, etc.) und einige weitere Faktoren, die bei der Entstehung der peripheren Neuropathie eine Rolle spielen (Sommer et al., 2018).

Die Neuropathie kann unterschiedlich ausgeprägt sein und dementsprechend auf verschiedene Weise in Erscheinung treten. Schmerzen oder auch ein kompletter Reizausfall des innervierten Gebietes sind möglich. Es kann zu einer Reflexminderung bis hin zu einer Areflexie oder schlaffen Parese der betroffenen Extremität kommen. Die häufigste Form ist die distal symmetrische periphere Neuropathie, bei der zunächst sensible Symptome in Form von Taubheitsgefühlen und Parästhesien auftreten. Möglich ist auch eine Small-FiberNeuropathie, die initial mit Schmerzen und Verlust des Temperaturempfindens einhergeht. Motorische Ausfälle treten vorwiegend im Verlauf auf (Cortez et al., 2014).

Es können sowohl einzelne (Mononeuropathie) aber auch mehrere Nerven gleichzeitig betroffen sein (Polyneuropathie).

Demyelinisierende Polyneuropathien können durch Autoimmunprozesse, Infektionserreger oder genetische Mutationen ausgelöst werden (Martin-Aguilar et al., 2019; Pareyson et al., 2017; Yuki, 2015). Eine Störung der Myelinscheide führt dann zu sensiblen Störungen (Parästhesien) der dicken Fasern und kann sich über die gesamte Länge des Nervs erstrecken (Kamil et al., 2019). Störungen der Vasa nervorum durch Vaskulitiden können ebenfalls zu 
einer Beeinträchtigung der Nerven führen, die zu sensorischen und motorischen Ausfällen führen können. Es gibt eine systemische und nicht-systemische, periphere Form (Blaes, 2015).

Axonopathien treten distal auf und können sowohl symmetrisch als auch asymmetrisch ausgeprägt sein. Häufige Ursachen von Axonopathien sind Diabetes mellitus, chronische Niereninsuffizienz, Nebenwirkungen von Chemotherapeutika oder auch Mangelerscheinungen (z.B. Vitamin B6, B12). Typischerweise imponieren Axonopathien durch distale, symmetrische strumpfförmige Verteilungsmuster der Extremitäten (Sommer et al., 2018).

Es gibt einen Zusammenhang zwischen dem Auftreten der peripheren Neuropathie und dem Blutglukosespiegel. So weist die Hälfte der Diabetiker Zeichen einer Neuropathie bzw. einer peripheren Neuropathie auf (Pop-Busui, 2009; Stino et al., 2017).

Callaghan et al. (2018) demonstrierten, dass ein steigender Blutglukosespiegel zu einem gehäuften Auftreten der peripheren Neuropathie führt. Einige der Patienten, die Neuropathien entwickelten, hatten lediglich einen Prädiabetes (Nüchternplasmaglukose $\geq 5,6 \mathrm{mmol} / \mathrm{l}$ und $<$ $7 \mathrm{mmol} / \mathrm{l}$, HbA1c-Werte $\geq 5,7 \%$ und $<6,5 \%$ ). Dies weist darauf hin, dass Neuropathien nicht nur bei Patienten mit einem manifesten DMII, sondern bereits bei Diabetesvorstufen auftreten können. Es wurden außerdem Daten einer Kohortenstudie verglichen und es wurde aufgezeigt, dass neben dem Blutzucker auch Adipositas Auslöser der Polyneuropathie ist. Es wird davon ausgegangen, dass auch andere Faktoren des metabolischen Syndroms eine Rolle spielen (Callaghan et al., 2018). In einer Untersuchung von Hanewinckel et al. (2016) wiesen Patienten mit Adipositas und MetS unabhängig vom Vorliegen eines DMII bereits Zeichen peripherer Neuropathien auf (Hanewinckel et. al 2016).

Vermutet werden inflammatorische, metabolische und vaskuläre Mechanismen, die im Rahmen eines MetS zur Aktivierung von Makrophagen führen, die wiederum in einer Kettenreaktion $\mathrm{zu}$ neurodegenerativen Veränderungen an peripheren Nerven beitragen (Callaghan et al., 2013). Darüber hinaus konnte eine weitere Studie zeigen, dass Diabetiker, die Risikofaktoren des MetS aufwiesen, eher Neuropathien entwickelten, als Diabetiker, die keine Zeichen des MetS boten (Bonadonna et al., 2006).

Eine persistente Hyperglykämie ist der wichtigste Parameter für das Auftreten späterer Komplikationen des DMII (Chisholm, 1993; Marcovecchio, 2017). Unabhängig vom DMII besteht ein Zusammenhang zwischen dem Auftreten von Neuropathien und anderen Faktoren des MetS. Etwa $16 \%$ der Diabetiker (Typ II) mit MetS wiesen eine periphere Neuropathie 
auf, wohingegen nur $6 \%$ der Diabetiker (Typ II) ohne MetS periphere Neuropathien aufzeigten. Der gemessene HbA1c-Wert sowie die LDL (low density lipoprotein) Partikelgröße wurden als unabhängige Risikofaktoren für das Auftreten der Neuropathie festgestellt (Isomaa ${ }^{2}$ et al., 2001). Der genaue Pathomechanismus über den Einfluss der LDLPartikel auf die periphere Neuropathie ist noch ungeklärt. Hyperlipidämie stellt einen weiteren Einflussfaktor bei der Entwicklung der diabetischen Neuropathie dar, wobei auch hier die Ätiologie noch unbekannt ist (Aguiar et al., 2015; Wiggin et al., 2009).

Der bisher etablierte Therapieansatz zur Prävention der peripheren Neuropathie ist die Behandlung und Einstellung des DMII. Ein Fortschreiten der Polyneuropathie kann durch konsequente Diät, Patientenschulungen, sowie durch die medikamentöse Therapie verlangsamt bzw. aufgehalten werden (Ismail- Beigi et al., 2010).

Bei der Entstehung der Neuropathien wird von einer chronischen Inflammation ausgegangen. Es werden Therapien entwickelt um in diese inflammatorische Kaskade einzugreifen (Martini et al., 2016). An diesem Inflammationsprozess sind unter anderem Chemokine, Kinasen oder Zytokine beteiligt (Kohl et al. 2010; White et al., 2007; Jin et Park, 2018). Diese stellen Angriffspunkte zur Behandlung der peripheren Neuropathie dar (Vinik et al., 2005). Auch antiinflammatorische Medikamente, wie Coxibe werden zur Behandlung der peripheren diabetischen Neuropathie untersucht (Kellogg et al., 2017).

\subsection{Eisen}

\subsubsection{Eisen und Adipositas}

Eisen ist ein Spurenelement, das im menschlichen Körper eine Reihe von Aufgaben erfüllt und ohne das ein Leben unmöglich wäre. Es kann in chemischen Verbindungen in zwei- oder dreiwertiger Form $\left(\mathrm{Fe}^{2^{+}}, \mathrm{Fe}^{3^{+}}\right)$auftreten. Die wichtigste Aufgabe ist die Bindung von Sauerstoff an rote Blutkörperchen und die Bildung von Hämoglobin oder Myoglobin, um eine suffiziente Gewebeoxygenierung sicherzustellen.

Im menschlichen Körper befinden sich etwa 3-5 g Eisen. Im Blutplasma ist Eisen an Transferrin, im Gewebe an Ferritin und Hämosiderin gebunden. Beispielsweise setzt sich bei einem 70 kg schweren Mann die Verteilung von Eisen wie folgt zusammen: Hämoglobin 2,8 g (66,1 \%), Myoglobin 0,2 g (4,7 \%), Cytochrome/ Katalasen/ Peroxidasen 0,01 g (0,2 \%), Nichthäm-Eisen 0,42 g (10\%), Transferrin 0,01 g (0,2 \%) und Depot-Eisen (Ferritin, 
Hämosiderin) 0,8 g (18,8 \%). Zur Deckung des Eisen-Tagesbedarfs müssen etwa $10 \mathrm{mg}$ täglich oral aufgenommen werden (Petrides, 2007).

Durch eine verminderte Eisenzufuhr oder Blutverlust kommt es zu einer Anämie (Warner et Kamran, 2018). So wichtig wie Eisen für verschiedenste Stoffwechselvorgänge in unserem Körper ist, hat es auch negative Einflüsse. Als freies Ion ist Eisen toxisch, ein Eisenüberschuss in Form einer Hämochromatose kann zu sekundären Organschäden führen (Kohgo et al., 2008). Erhöhte Eisenwerte stellen einen Risikofaktor für koronare Herzerkrankungen wie Arteriosklerose und Herzinfarkt dar, da freie Eisenionen die Bildung von Sauerstoffradikalen (ROS) fördern. Diese sind sehr reaktionsfreudig und haben eine direkte schädigende Wirkung auf eine Vielzahl zellulärer Verbindungen (Kohen et. al, 2002). In einigen Humanstudien konnte ein Zusammenhang zwischen Adipositas, MetS, DMII und dem Eisenstoffwechsel festgestellt werden. Erhöhte Eisenspeicher waren mit Adipositas und dem MetS assoziiert (Bozzini et al., 2005; Hubler et al., 2015; Shim et al., 2017). Außerdem zeigte sich, dass erhöhte Konzentrationen an Serumferritin und Zelleisen mit einem hohen Risiko einhergehen, an DMII zu erkranken (Hubler et al., 2015).

Aus oben genannten Gründen muss der Eisenstoffwechsel einer strengen Kontrolle durch den Körper unterliegen. Eines der wichtigsten Hormone, das die Homöostase des Eisens reguliert, ist Hepcidin. Hepcidin ist ein antimikrobielles Peptidhormon aus 25 Aminosäuren (Agarwal et Yee, 2019; Krause et al., 2000). Überwiegend wird es in der Leber, aber auch im Herzen, Pankreas, Nieren, Milz und sogar von Adipozyten synthetisiert (Bekri et al., 2006; Kulaksiz et al. 2005; Kulaksiz et al., 2008; Lakhal-Littleton et al., 2016; Sarafidis et al., 2012). Außerdem verhindert es durch die Hemmung des Ferroportins die Eisenfreisetzung aus dem retikuloendothelialen System (RES). Die Hepcidinsynthese in der Leber wird durch folgende Stimuli gesteigert: Inflammation, Infektion, ER (endoplasmatisches Retikulum)-Stress, erhöhte Konzentrationen an Serumeisen und gesättigtem Transferrin. Hingegen führen Hypoxie, erythropoetische Aktivität, Eisenmangel, Anämie und Mutationen des Hepcidingens zu einer verminderten Hepcidinsynthese (Ganz et Nemeth, 2006; Pantopolous et al., 2012).

Ein zunehmender Hepcidinspiegel hemmt Ferroportin 1 (FPN) der Enterozyten und Makrophagen. Die Eisenaufnahme über den Darm wird limitiert, sodass weniger Eisen zur Verfügung gestellt wird. Außerdem verhindert es durch die Hemmung des FPN die Eisenfreisetzung aus dem RES. FPN schleust Eisen in Form des Transporteisens $\left(\mathrm{Fe}^{2^{+}}\right)$aus der Zelle. Im Rahmen einer Oxidation mit z.B. Hephästin $(\mathrm{H})$ oder auch Coeruloplasmin, wird $\mathrm{Fe}^{2+} \mathrm{zu} \mathrm{Fe}{ }^{3+}$ oxidiert. Das an Transferrin gebundene $\mathrm{Fe}^{3+}$ wird im Blut transportiert und kann 
über Transferrinrezeptoren der Makrophagenmembran gebunden und aufgenommen werden. Aus der Nahrung wird Hämeisen in die Zelle aufgenommen und über den Heme Carrier Transporter 1 (HCP) durch Hämoxygenase $\mathrm{zu} \mathrm{Fe}^{3+}$ oxidiert. Dieses wird an Ferritin gebunden und kann auf diese Weise in der Zelle gespeichert werden. $\mathrm{Fe}^{3+}$ kann durch Zytochrom B (ZCB) $\mathrm{zu} \mathrm{Fe}^{2+}$ reduziert werden und durch den Divalent Metal Transporter 1 (DMT) in die Enterozyten gelangen (Abbildung 1).

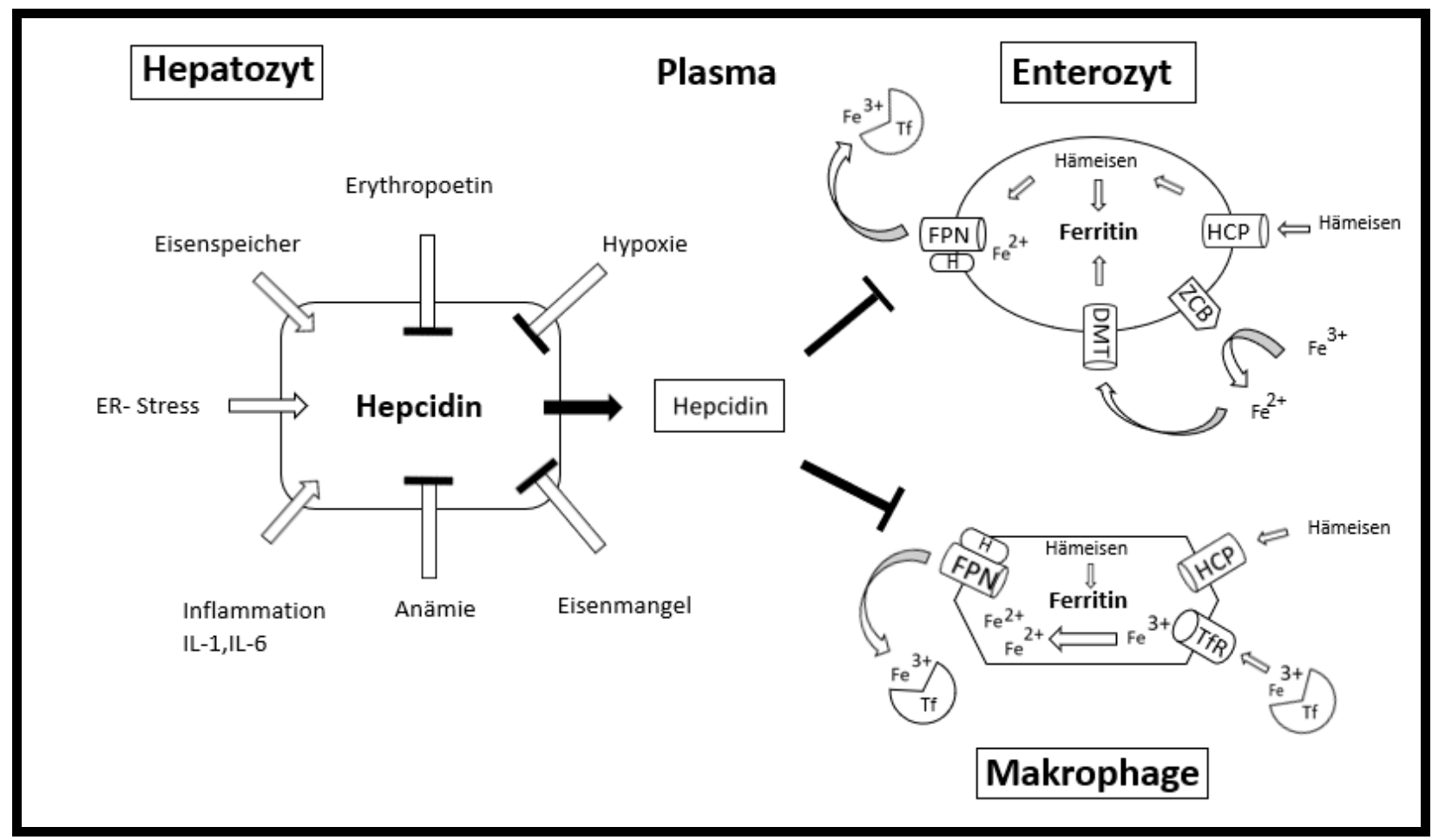

Abb.1: Schematische Darstellung der Wirkung von Hepcidin auf den Eisenstoffwechsel, modifiziert nach Larson und Coyne, 2013.

[DMT: divalent metal transporter 1; FPN: Ferroportin 1; H: Hephästin; HCP: heme carrier transporter 1; Tf: Transferrin, TfR; Transferrinrezeptor 1; ZCB: Zytochrom B].

Hepcidin regelt außerdem den Eisenstoffwechsel im Rahmen chronischer Entzündungen (Ganz et Nemeth, 2006). Wird vermehrt IL-6 freigesetzt, kommt es zu einer gesteigerten Hepcidinsynthese in den Hepatozyten. Dadurch wird Eisen in den Makrophagen gehalten und alte Erythrozyten können nicht verstoffwechselt werden. Auf diesem Weg wird Hämeisen nicht recycelt, sodass in Folge eine entzündungsbedingte Anämie resultiert. Im Sinne einer negativen Rückkopplung hemmt eine Anämie wiederum die Hepcidinsynthese (Ganz et Nemeth, 2006). 
Durch frühere Untersuchungen konnte ein Zusammenhang zwischen Eisenstoffwechsel und Adipositas hergestellt werden (Moayeri et al., 2006; Orr et al., 2014; Sarafidis et al., 2012; Yanoff et al., 2007).

Wie bereits beschrieben, wird Adipositas mit einer chronischen Entzündung assoziiert. Mit steigender Konzentration an IL-6 kommt es zu einer erhöhten Hepcidinkonzentration (Bekri et al., 2006). Es resultiert ein Eisenmangel. Studien um Zafon et al. (2010) konnten anhand adipöser Patienten zeigen, dass Leptin zu einer gesteigerten Hepcidinsynthese führt (Zafon et al., 2010). Leptin ist ein Adipokin, das von Adipozyten sezerniert wird (Zhang et al., 1994). Bei Patienten mit Adipositas wird dementsprechend weniger Eisen aus den Eisenspeichern freigesetzt als bei Normalgewichtigen. Patienten mit Adipositas weisen geringere Konzentrationen an Serumeisen als Vergleichspatienten auf (Yanoff et al., 2007). Insgesamt führt die erhöhte Konzentration an proinflammatorischen Zytokinen (z.B. IL-6, TNF- $\alpha$ ) zu einer gesteigerten Hepcidinsynthese und dadurch zu einer verminderten Eisenresorption (Cepeda- Lopez et al.; 2015 Monteiro et al., 2010).

Aber nicht nur Adipozyten haben Einfluss auf den Eisenstoffwechsel. Auch Eisen selbst wirkt sich auf den Stoffwechsel der Adipozyten aus. Durch überschüssiges freies Eisen wird die Bildung von ROS angeregt. Dadurch wird der Stoffwechsel in den Adipozytenmakrophagen selbst gestört (Hubler et al., 2015).

\subsubsection{Eisen und oxidativer Stress}

Oxidativer Stress stellt ein Ungleichgewicht von schützenden und schädlichen enzymatischen Reaktionen im menschlichen Körper dar. Vor allem durch Cytochrom-P450-Oxidasen katalysierte sauerstoffabhängige Redoxreaktionen werden ROS gebildet. Sie besitzen durch ihre hohe Reaktionsfreude schädigendes Potential und können zu Gewebsuntergang oder DNA-Schädigung führen (Bergamini et al., 2004; Kohen et al., 2002). Zu den ROS gehören unter anderem freie Radikale, wie Superoxidradikalion, Perhydroxyl- und Hydroxylradikal.

Um diese reaktionsfreudigen Elemente wieder unschädlich zu machen, stellt der Organismus unter anderem die Superoxiddismutase bereit. Diese wandelt Superoxidanionen zu Wasserstoffperoxid $\left(\mathrm{H}_{2} \mathrm{O}_{2}\right)$ und Sauerstoff $\left(\mathrm{O}_{2}\right)$ um. Katalase und Gluthationperoxidase reagieren anschließend mit $\mathrm{H}_{2} \mathrm{O}_{2} \mathrm{zu}$ Wasser und Sauerstoff (Kohen et al., 2002).

Fällt nun vermehrt ROS an, kommt es zu oxidativem Stress. Folgen des oxidativen Stresses sind pathologische Mechanismen wie z.B. Lipidperoxidation, Proteinoxidation und DNASchädigung, die zum Zelltod führen können. Dennoch ist eine gewisse Menge an ROS für 
einige physiologische Prozesse wie Chemotaxis, Hormonsynthese, Immunantwort, Gewebsumbau und Calciumstoffwechsel notwendig (Sena et Chandel, 2012).

Eisen spielt eine wichtige Rolle bei der Fentonreaktion, einer Redoxreaktion unter der Bildung von ROS (Fenton, 1894). Es wirkt als Katalysator dieser Reaktion und kann bei entsprechendem Überschuss zu einer vermehrten ROS-Bildung und somit zu verstärkten oxidativen Stress und Gewebsuntergang führen.

Es bestehen Hinweise auf einen Zusammenhang zwischen Eisenüberladung und dem Auftreten bestimmter Erkrankungen, unter anderem kardiovaskuläre Krankheiten, DMII oder Tumore, wie das hepatozelluläre Karzinom (Huang et al., 2011; Kew, 2014; Merono et al., 2011).

Der Körper stellt Antioxidantien, unter anderem mittels der Superoxiddismutase zur Verfügung, um ROS zu eliminieren. Unter bestimmten Bedingungen können jedoch körpereigene Antioxidantien oxidativen Stress nicht neutralisieren. In diesem Fall kommen andere durch die Nahrung zugeführte Antioxidantien zum Einsatz. Einige dieser Antioxidantien regulieren den Eisenstoffwechsel und eignen sich daher hervorragend zur Behandlung von oxidativem Stress bei Eisenmangel und Eisenüberladung (Imam et al, 2017). Zwei Beispiele für exogene Antioxidantien sind Resveratrol, das unter anderem die eiseninduzierte kardiale Eisenüberladung sowie oxidativen Stress reduziert, aber auch Vitamin C, das die Reduktionsreaktion von $\mathrm{Fe}^{3^{+}} \mathrm{zu} \quad \mathrm{Fe}^{2^{+}}$katalysiert und die Hepcidinexpression inhibiert (Chiu et al. 2012; Das et al., 2015).

\subsubsection{Eisen und neurodegenerative Erkrankungen}

In den vergangenen Jahren wurde eine Verbindung zwischen dem Eisenstoffwechsel und dem Auftreten neurodegenerativer Erkrankungen (NE) untersucht. Störungen des Eisenstoffwechsels wurden unter anderem bei Morbus Huntington, Amyotropher Lateralsklerose, Morbus Alzheimer, Friedreich-Ataxie und Morbus Parkinson beobachtet (Ward et al., 2014).

In einer Metaanalyse von Wang et. al (2016) wurden bei Patienten mit Morbus Parkinson zerebral erhöhte Eisenkonzentrationen vor allem in der Substantia nigra nachgewiesen. Im Kontrast dazu fand man eher geringe Eisenwerte im Globus pallidus (Pichler et al., 2013; Wang et. al, 2016). Der genannte Eisenüberschuss beim Morbus Parkinson korreliert mit einer zunehmenden Produktion von ROS, das wiederum zu einer Neurodegeneration des Gehirns führen kann (Altamura, 2009). 
Eine weitere neurodegenerative Krankheit des Zentralnervensystems stellt die Demenz vom Typ Alzheimer dar. Patienten mit Alzheimer weisen signifikant höhere Bluteisenspiegel auf. Neben Eisen waren noch andere Spurenelemente wie Zink und Kupfer deutlich erhöht (Victor et al., 2017). Freies Eisen geht Verbindungen ein, die zu toxischen Reaktionen in der Nervenzelle mit konsekutiver Freisetzung von ROS führen und damit zum Zelluntergang beitragen (Bonda et al., 2011; Manoharan et al., 2016).

Das Restless-Legs-Syndrom (RLS) gehört ebenfalls zu den NE, die veränderte Eisenspiegel aufweisen. Studien verglichen den Eisengehalt von Mitochondrien RLS-erkrankter Patienten mit dem von gesunden Vergleichsprobanden. Patienten mit RLS wiesen einen Eisenmangel auf (Haschka et al., 2019). Inwieweit sich der Eisenmangel von Mitochondrien auf diese Erkrankung auswirkt, ist noch nicht ausreichend geklärt. Eine weitere Studie konnte einen Zusammenhang zwischen verminderten Eisenkonzentrationen im Gehirn und der Pathogenese des RLS herstellen (Salas et al., 2010). Ein vielversprechender Ansatz zur Behandlung des RLS stellt die Eisensubstitution dar. Durch die orale oder parenterale Eisensubstitution konnte ein positiver Effekt auf die RLS-Symptomatik erzielt werden (Avni et al., 2019).

In einer Studie um Baum et al. (2016) konnte anhand von Streptotozotin (STZ)-Ratten der Einfluss der exogenen Eisenzufuhr auf die periphere diabetische Polyneuropathie demonstriert werden. Hierfür wurde ein Tiermodell des Diabetes mellitus Typ 1 gewählt. Dieser wurde durch die Einmalgabe von STZ in 4 Monate alte Sprague-Dawley Ratten induziert.

STZ-diabetische Ratten und nichtdiabetische Ratten wurden mit hoher, standard- oder eisenarmer Ernährung gefüttert. 3 Monate nach diätetischer Intervention wurden die Tiere untersucht.

STZ-Ratten, denen normale Eisenmengen zugeführt wurden, zeigten einen manifesten Diabetes, eine verlangsamte motorische Nervenleitgeschwindigkeit, eine ausgeprägte Degeneration von distalen intraepidermalen Nervenfasern, eine intraneurale Einwanderung von Makrophagen und T-Zellen in den Ischiasnerv, sowie erhöhte Eisenspiegel in Serum und in dorsalen Spinalganglienneuronen. Während die motorischen Fasern in allen STZ-Gruppen betroffen waren, führte nur die Diät mit geringer Eisenzufuhr zusätzlich zu reduzierten sensorischen Leitgeschwindigkeiten im Ischiasnerv. Nur STZ-Ratten mit einer eisenarmen Ernährung wiesen geschädigte Mitochondrien in mehreren Spinalganglieneuronen auf. Hier wurde ebenfalls eine tiefere intraepidermale Nervenfaserdegeneration festgestellt. Es zeigte sich im Vergleich zu den anderen Gruppen eine geringe Faserneuropathie bei zeitgleich erhöhter Anzahl von Entzündungszellen in den Ischiasnerven. Zusammenfassend war 
vielmehr ein diätetischer Eisenmangel statt einer Eisenüberladung in Kombination mit einer leichten Entzündung bei einer Neuropathie der Diabetes-induzierten peripheren diabetischen Polyneuropathie assoziiert (Baum et al., 2016).

Ein weiteres Tierexperiment mit $d b / d b$-Mäusen beschäftigte sich mit dem Einfluss von Eisen und neuronaler Inflammation auf die DMII-induzierte periphere Neuropathie. In einer Studie unserer Arbeitsgruppe (Paeschke et al. 2019) wurde ein Tiermodell gewählt, in dem Adipositas und DMII gemeinsam auftraten. 3 Monate alte $d b / d b$-Mäuse wurden mit hoher, standard- oder eisenarmer Ernährung gefüttert. 4 Monate nach diätetischer Intervention wurden die Tiere untersucht. Eine eisenreiche Diät führte zu einer signifikanten Zunahme der motorischen Nervenleitgeschwindigkeiten im Vergleich zu den Mäusen mit Standard- oder Eisenmangeldiät. Außerdem kam es unter eisenreicher Diät zu einer Senkung des Blutglukosespiegels und der HbAlc-Konzentration. Die Anzahl proinflammatorischer Makrophagen war in Nervenabschnitten vermindert und entzündungshemmende Makrophagen waren bei $d b / d b$-Mäusen mit hoher Eisendiät im Vergleich zu den anderen Gruppen erhöht. Damit ergeben sich weitere Hinweise darauf, dass eine vermehrte Eisenzufuhr die Entwicklung der peripheren diabetischen Neuropathie zum Teil aufhalten kann, wohingegen eine Eisenmangeldiät die periphere diabetische Polyneuropathie eher fördert (Paeschke et al., 2019).

Oshiro et al. (2011) befassten sich ebenfalls mit dem Einfluss des Eisens auf NE. Es konnte gezeigt werden, dass Störungen des Eisenstoffwechsels die Produktion neurologischer Substanzen, unter anderem ROS, vorantreiben und damit zu oxidativem Stress in den Nervenzellen führen (Oshiro et al., 2011). Auch hier gibt es therapeutische Ansätze zur Bekämpfung von NE, die mit einer Eisenüberladung assoziiert sind. Dabei wird versucht, Eisen durch Chelatoren abzufangen (Nunez et al., 2018). Dadurch könnten neurotoxische Effekte vermindert oder gar aufgehalten werden. Aktuell finden sich nur wenige Studien bezüglich Nebenwirkungen, Dosierungen und Spezifität der Chelatorengabe bei NE.

In Zusammenschau der hier genannten Studien wird deutlich, dass es einen Zusammenhang zwischen gestörtem Eisenstoffwechsel und dem Auftreten von NE geben muss. 


\section{Ziel der Arbeit}

Es ist bereits bekannt, dass Übergewicht mit einer lipidinduzierten Inflammationsreaktion des Körpers einhergeht. Studien demonstrierten, dass diese Entzündungsreaktionen Einfluss auf die Entwicklung der Polyneuropathie haben.

Ziel dieser Arbeit war es, einen Zusammenhang zwischen Adipositas, MetS, Eisenaufnahme und dem Inflammationsprozess an peripheren Nerven herzustellen. Es sollte untersucht werden, wie sich Eisen auf die Polyneuropathie auswirkt. Hier wurde TNF- $\alpha$ als Inflammationsparameter verwendet, da dieser unter anderem eine wichtige Rolle bei der Insulinresistenz und Nervendegeneration übergewichtiger Patienten sowie bei diabetischen Neuropathien spielt. Als Tiermodell wurden adipöse leptindefiziente $o b / o b$-Mäuse mit MetS ausgewählt.

Wir wollten aktuelle Therapiestrategien, bei denen Eisenchelatoren zur Behandlung der diabetischen peripheren Neuropathien zum Einsatz kommen, kritisch hinterfragen. Die Datenlage hierzu ist limitiert.

Das Ziel dieser Arbeit wurde unter folgenden Fragestellungen durchgeführt:

1. Beeinflusst eisenarme- bzw. eisenreiche Diät die physiologischen Funktionen des Nervus ischiadicus der $o b / o b$-Mäuse?

2. Welchen Effekt hat Nahrungseisen auf die Morphologie der peripheren Nerven und auf die Nervenendigungen in der Haut?

3. Welchen Effekt hat nahrungsbedingter Eisenmangel bzw. -überschuss auf die Infiltration der proinflammatorischen Zellen im Nervus ischiadicus der Experimenttiere?

4. Beeinflusst das eisenarme bzw. eisenreiche Futter die Expression von proinflammatorischen Zytokinen im Nervus ischiadicus der $o b / o b$-Mäuse?

\section{Material/ Methoden}

\subsection{Mausmodell}

Für die Experimente wurden 3 Monate alte männliche homozygote $o b / o b$ und heterozygote $o b /+$ Mäuse verwendet. Die Mutation des Leptingens führt zur Ausprägung typischer Merkmale des metabolischen Syndroms. Die Mäuse entwickeln eine Insulinresistenz und Hyperphagie. Außerdem weisen sie einen Körperfettanteil von über $50 \%$ auf und nach etwa 5 Lebensmonaten kann, wenn überhaupt, eine milde Hyperglykämie festgestellt werden 
(Haluzik et al., 2004). Leptindefiziente Mäuse sind Tiermodelle zur Untersuchung von Veränderungen der Nervenleitgeschwindigkeit in Zusammenhang mit Adipositas oder dem MetS (Drel et al., 2006).

In dieser Arbeit wurden 18 Tiere der homozygoten ob/ob Mäuse und 18 Tiere der heterozygoten $o b /+$ Mäuse verwendet. Eine Genehmigung für die Tierversuche wurde durch die Landesdirektion Sachsen, sowie die Ethikkommission des Universitätsklinikums Leipzig bewilligt. Die Mäuse wurden in jeweils 3 Gruppen à 6 Tiere der $o b / o b$ und $o b /+$ Mäuse eingeteilt. Die Tiere wurden über 4 Monate durch Futter mit unterschiedlichen Eisenkonzentrationen ernährt (Altromin Spezialfutter, 32791 Lage, Deutschland). Eine Gruppe erhielt eine hohe Eisenkonzentration (29 g/kg), eine Gruppe wurde mit Futter in Standardeisenkonzentration gefüttert $(178 \mathrm{mg} / \mathrm{kg})$ und eine weitere Gruppe bekam Futter mit einer niedrigen Eisenkonzentration $(5 \mathrm{mg} / \mathrm{kg})$.

Die Blutglukosekonzentration wurde aus dem Vollblut der Schwanzvene mit einem Optimum Omega Glukosemeter (GlucoMen, Menarini Diagnostics, Berlin, Deutschland) bestimmt. Die Serumeisenkonzentrationen wurden mit Cobas ${ }^{\circledR} 8000$ Modulanalysegerät gemessen (Roche Diagnostics). Die sensorischen und motorischen Nervenleitgeschwindigkeiten wurden von den linken Ischiasnerven der Mäuse abgeleitet. Als proximaler Ableitungspunkt wurde die Bifurkation der Ischiasnerven gewählt und distal wurden die Elektroden am Fußknöchel angebracht. Die Nadelelektroden wurden uns durch Prof. C. Karup (Kopenhagen) zur Verfügung gestellt. Alle Werte wurden durch die Neurosoft-Evidence 3102Elektromyograph-Software berechnet (Schreiber und Tholen, Stade, Deutschland). Es wurden Proben des Ischiasnervs und peripherer Nerven der Fußhaut entnommen und eingefärbt. Dazu wurden zunächst polyklonale Calcium-Rezeptor-Antikörper (anti-Iba-1) zur Makrophagenmarkierung bzw. polyklonale anti-CD3-Antikörper zur T-Zell-Markierung gewählt. Danach erfolgte die Färbung mit monoklonalen Antikörpern gegen Neurofilament 200, sowie CD68 zur Detektion stimulierter Makrophagen.

Anschließende Messungen der Nervenfaserdichte wurden mit Zeiss Software (Zeiss LSM Image Browser) realisiert. Zuvor eingefärbte Makrophagen und T-Zellen wurden mit dem LSM 510 Meta- konfokalen Mikroskop (Zeiss) aufgenommen und konnten ausgezählt werden. Durch Westernblot-Analyse konnte die Entzündungsreaktion im Gewebe nachgewiesen werden. Die für die Versuchsreihen verwendeten Antikörper sind in Tabelle 2 (Tab.2) aufgeführt. 
Tab.2: Liste der verwendeten Antikörper mit Verdünnung und Hersteller

\begin{tabular}{|c|c|c|}
\hline Antikörper & Verdünnung & Hersteller \\
\hline $\begin{array}{c}\text { rabbit polyclonal } \\
\text { microglia/macrophage } \\
\text { cytoplasmatic calcium } \\
\text { adaptor (anti- Iba- 1) }\end{array}$ & $1: 200$ & $\begin{array}{c}\text { WAKO Chemicals USA, } \\
\text { Richmond, VA }\end{array}$ \\
\hline $\begin{array}{c}\text { Rabbit polyclonal anti-CD3 } \\
\text { mouse monoclonal anti- } \\
\text { neurofilament 200 }\end{array}$ & $1: 200$ & $\begin{array}{c}\text { Dako Cytomation, Hamburg, } \\
\text { Deutschland }\end{array}$ \\
\hline $\begin{array}{c}\text { Polyclonal antibody anti- } \\
\text { PGP 9.5 }\end{array}$ & $1: 500$ & $\begin{array}{c}\text { Sigma Aldrich, Taufkirchen, } \\
\text { Deutschland }\end{array}$ \\
\hline $\begin{array}{c}\text { Mouse monoclonal antibody } \\
\text { anti- CD68 }\end{array}$ & $1: 1000$ & Abcam, Cambridge, UK \\
\hline rabbit polyclonal anti- \\
TNFalpha
\end{tabular}




\title{
The role of dietary non-heme iron load and peripheral nerve inflammation in the development of peripheral neuropathy (PN) in obese non-diabetic leptin-deficient ob/ob mice
}

\author{
Joanna Kosackaa*, Katrin Woidt ${ }^{\mathrm{b} *}$, Klaus V. Toykac, Sabine Paeschke ${ }^{\mathrm{b}}$, Nora Klöting ${ }^{\mathrm{de}}$, Ingo Bechmann , \\ Matthias Blüher ${ }^{d}$, Joachim Thieryf, Susann Ossmann ${ }^{\mathrm{q}}$, Petra Baum ${ }^{\text {a* }}$ and Marcin Nowickib*

\begin{abstract}
aDepartment of Neurology, University of Leipzig, Leipzig, Germany; 'bnstitute of Anatomy, University of Leipzig, Leipzig, Germany; 'Department of Neurology, University of Würzburg, Würzburg, Germany; ${ }^{d}$ Department of Medicine, University of Leipzig, Leipzig,

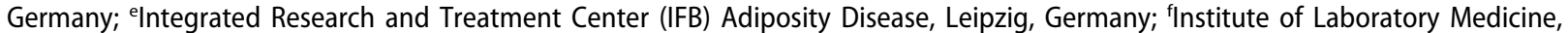
Clinical Chemistry and Molecular Diagnostics (ILM), University of Leipzig, Leipzig, German; ${ }^{9}$ Heart Center, University of Leipzig, Leipzig Germany
\end{abstract}

\begin{abstract}
Introduction: Here, we investigated inflammatory signs of peripheral nerves in leptindeficient obese $o b / o b$ mice and the modulating effects of the exogenous iron load.

Methods: $\mathrm{Ob} / \mathrm{ob}$ and $\mathrm{ob} /+$ control mice were fed with high, standard, or low iron diet for four months.

Results: We found intraepidermal nerve fiber degeneration in foot skin and low-grade neuropathic abnormalities including mildly slowed motor and compound sensory nerve conduction velocities and low-grade macrophage and T-cell infiltration without overt neuropathology in sciatic nerves of all ob/ob mice. Low dietary iron load caused more pronounced abnormalities than high iron load in ob/ob mice.

Discussion: Our data suggest that dietary non-heme iron deficiency may be a modulating factor in the pathogenesis of peripheral neuropathy in obese $o b / o b$ mice with metabolic syndrome. Once the mechanisms can be further elucidated, how low dietary iron augments peripheral nerve degeneration and dysfunction via pro-inflammatory pathways and new therapeutic strategies could be developed.

Abbreviations: CMAP: compound muscle action potential; cSNCV: compound sensory nerve conduction velocity; IENFD: intraepidermal nerve fiber density; LDL: low-density lipoprotein; MetS: metabolic syndrome; MNCV: motor conduction velocity; NCV: nerve conduction velocity; PN: peripheral neuropathy; PNS: peripheral nervous system; STZ: streptozotocin; T2D: type 2 diabetes mellitus; TNF alpha: tumor necrosis factor alpha; WHO: World Health Organization
\end{abstract}

ARTICLE HISTORY

Received 13 November 2018 Accepted 24 December 2018

\section{KEYWORDS}

Peripheral neuropathy; $o b / o b$ mice; iron; nerve inflammation; metabolic syndrome

\section{Introduction}

The worldwide prevalence of overweight, obesity, and their metabolic complications has increased dramatically over the last decades. In 2016, it was estimated that more than 1.9 billion adults were overweight, and of these, over 650 million were obese (WHO, 2017). Excessive fat accumulation is often associated with chronic inflammation, insulin resistance, impaired glucose tolerance, hyperlipidemia, hypertension, metabolic syndrome (MetS), and type 2 diabetes (T2D) $[1,2]$.

In the peripheral nervous system (PNS), obesity-, MetS-, and T2D-related alterations may all affect nerve function and cause peripheral neuropathy (PN) [2-7]. The putative pathophysiology of PN includes metabolic, vascular, and inflammatory mechanisms, but a unifying hypothesis of the culprit pathogenic factors does still not exist $[2,8,9]$. PN leads to degeneration and impaired regeneration of nerve axons associated with structural and functional changes in endoneurial and epineural microvessels and in Schwann cells in afflicted humans [7,10-14]. Indeed, patients with obesity and MetS have a higher prevalence of developing $\mathrm{PN}$, even in the absence of hyperglycemia when compared to the lean control population $[2,15,16]$.

Several animal models and human studies have recently shown an association between obesity, MetS, T2D, and deranged iron homeostasis [17-25]. Iron deficiency has been found in patients with advanced stages of obesity, whereas increased iron levels have been demonstrated in many patients suffering from MetS or T2D $[17,18]$. Increased body iron storage enhances the generation of free radicals [26]. Free radicals are highly reactive species promoting oxidation of proteins, peroxidation of membrane lipids, and modification of nucleic acids $[27,28]$ and are implicated in the pathogenesis of several neurological diseases [23,24,29-31]. Iron may also 
act in Schwann cell differentiation, peripheral nerve myelination, and regeneration [23].

Following up on our previous studies on the negative role of low iron in a streptozotocin (STZ)-diabetes rat model [32] and in diabetic $d b / d b$ mice (Paeschke, Nowicki et al., unpublished data 2018), we here investigated the effects of increased or reduced exogenous iron load on the severity of PN in leptin-deficient $o b / o b$ mice as an animal model of obesity and MetS. Ob/ob mice may show deficits in nerve conduction velocity (NCV), nerve fiber abnormalities, and endoneurial microvessel changes in the sciatic nerve $[13,33,34]$. Metabolically, as a result of a mutation in the gene encoding leptin, $o b / o b$ mice exhibit over $50 \%$ body fat, insulin resistance, hyperphagia, and mild and transient, if any, hyperglycemia which disappears around 5 months of age [35]. In line with our previous study [32], we found that chronic iron depletion rather than iron overload augments peripheral nerve pathology and pro-inflammatory activity in $o b / o b$ mice.

\section{Methods}

\subsection{Animals}

A total number of 21 male $o b / o b\left(L e p^{o b} / L^{\circ e p^{\circ b}}\right)$ homozygous and of 21 male $o b /+\left(\right.$ Lepr $\left.^{o b} /+\right)$ heterozygous 3-month-old mice were used in this study. The experiments had been approved by the state authorities (Landesdirektion Sachsen, reg. no.: TVV 63/12). Animals were randomly assigned to three $o b / o b$ and three $o b /+$ treatment groups of seven mice each. All six groups of mice were fed ad libitum with three different chows for 4 months exclusively (Altromin, Lage, Germany). The chows contained (1) high iron (29 g/ $\mathrm{kg}$ - standard diet complemented with 3\% carbonyl iron), (2) standard iron (178 $\mathrm{mg} / \mathrm{kg})$, or (3) low iron $(5 \mathrm{mg} / \mathrm{kg})$ concentration. Blood glucose concentrations were measured before and during the experimental period in whole blood taken from the lateral tail vein using an Optium Omega glucometer (GlucoMen, Menarini Diagnostics, Berlin, Germany). Serum iron levels were measured with Cobas 8000 modular analyzer (Roche Diagnostics) using a colorimetric test by Roche Diagnostics (Berlin, Germany) based on the FerroZine method without deproteination.

\subsection{Electrophysiology}

NCVs were analyzed in the left sciatic nerve as described elsewhere [36,37]. In brief, we measured motor and compound sensory NCVs (MNCV and cSNCV). The sciatic notch was used as the proximal stimulation point (S1) in motor NCV and as the proximal pick-up point for compound SNCV using nearnerve needle electrodes (kindly provided by Prof. C. Krarup, Copenhagen) [37]. A pair of bare steel needle electrodes was inserted at the ankle as the distal stimulation point (S2). Recording electrodes for the compound muscle action potentials (CMAP) were placed between digits 2 and 3 (active electrode) and at the base of digit 5 of the left foot. The MNCVs were calculated by dividing the distance between the two stimulation points by the differences in latencies of the CMAPs after proximal and distal supramaximal stimulation. Compound sensory nerve action potentials (cSNAP) were recorded with the near-nerve electrodes that had served as proximal stimulation electrodes for MNCVs. Stimulation electrodes at the ankle were the same electrodes as used for eliciting distal CMAPs. The cSNCVs were calculated by dividing the distance between stimulation and recording electrodes by the latency of the first positive peak of the cSNAP. All parameters were calculated semi-automatically using the Neurosoft-Evidence 3102 electromyograph software (Schreiber und Tholen, Stade, Germany).

\subsection{Immunostaining}

Mice ( $n=5$ per group) were perfused and sciatic nerves and hindfoot skin biopsies were dissected and prepared as previously described [38]. Sections were double stained by first incubating with rabbit polyclonal antibodies directed at the microglia/macrophage cytoplasmic calcium adaptor (anti-Iba-1) for the detection of macrophages (1:200; WAKO Chemicals USA, Richmond, VA) or with rabbit polyclonal anti-CD3 antibodies for detection of T-cells (1:200; Dako Cytomation, Hamburg, Germany). Second, the mouse monoclonal antibody against neurofilament 200 (NF200; 1:500; Sigma Aldrich, Taufkirchen, Germany) was used to identify nerve axons or the mouse monoclonal antibody against CD68 (ED1) for the detection of activated macrophages (1:200, Abcam, Cambridge, UK). For identification of intraepidermal small nerve fibers, polyclonal antibody against the axonal protein gene product (PGP 9.5; 1:1000; Abcam) was used. Next, the immunostaining was conducted as described elsewhere [38].

\subsection{Quantification of the intraepidermal nerve fiber density (IENFD)}

We prepared $30-\mu \mathrm{m}$-thick skin sections from the hindfoot of $o b / o b$ and $o b /+$ mice $(n=3$ per experimental group) and stained them using the immunostaining methods described above. The number of PGP 9.5-positive fibers crossing the dermal-epidermal junction and individual fibers in the dermis and epidermis was counted for each randomly selected section (five per one animal) and divided by the epidermal length measured using Zeiss software (Zeiss LSM image Browser). All sections were analyzed by an observer blinded as to the dietary treatment groups. 
Table 1. Biochemical and physiological parameters of $o b / o b$ and $o b /+$ control mice fed with high iron, standard iron, and low iron diet. Values represent means \pm SD of six animals ( $n=6$; blood samples were collected between 8 a.m. and 9:30 a.m.).

\begin{tabular}{|c|c|c|c|c|c|c|}
\hline \multirow[b]{2}{*}{ Parameter } & \multicolumn{2}{|c|}{ High iron } & \multicolumn{2}{|c|}{ Standard } & \multicolumn{2}{|c|}{ Low iron } \\
\hline & $o b / o b$ & $o b /+$ & $o b / o b$ & $o b /+$ & $o b / o b$ & $o b /+$ \\
\hline Blood glucose $(\mathrm{mmol} / \mathrm{l})$ & $5.45 \pm 0.98$ & $5.68 \pm 1.84$ & $5.17 \pm 0.92$ & $5.83 \pm 1.40$ & $6.52 \pm 0.09$ & $6.12 \pm 0.81$ \\
\hline Serum insulin $(\mathrm{ng} / \mathrm{ml})$ & $5.03 \pm 4.64$ & $0.73 \pm 0.55$ & $12.88 \pm 4.05$ & $0.86 \pm 0.45$ & $15.24 \pm 1.44$ & $0.71 \pm 0.35$ \\
\hline Body weight $(g)$ - start & $54.25 \pm 2.90$ & $30.33 \pm 1.04$ & $54.57 \pm 6.67$ & $31.07 \pm 1.70$ & $54.43 \pm 1.87$ & $30.88 \pm 1.65$ \\
\hline Body weight $(\mathrm{g})$ - end & $65.27 \pm 2.41$ & $33.30 \pm 1.73$ & $67.68 \pm 4.38$ & $38.30 \pm 3.30$ & $67.33 \pm 3.40$ & $36.33 \pm 3.09$ \\
\hline$\%$ of fat of the body weight & $51.82 \pm 0.92$ & $11.33 \pm 2.88$ & $54.86 \pm 3.29$ & $21.89 \pm 4.86$ & $56.44 \pm 2.03$ & $15.69 \pm 8.16$ \\
\hline Total cholesterol $(\mathrm{mmol} / \mathrm{l})$ & $5.2 \pm 0.43$ & $2.96 \pm 0.82$ & $6.32 \pm 1.82$ & $3.79 \pm 0.44$ & $6.31 \pm 1.68$ & $3.71 \pm 0.28$ \\
\hline LDL-cholesterol (mmol/l) & $1.77 \pm 0.24$ & $0.66 \pm 0.51$ & $2.14 \pm 0.58$ & $1.21 \pm 0.15$ & $2.53 \pm 0.94$ & $0.61 \pm 0.10$ \\
\hline Triglyceride $(\mathrm{mmol} / \mathrm{l})$ & $0.56 \pm 0.11$ & $1.10 \pm 0.48$ & $0.94 \pm 0.29$ & $0.71 \pm 0.28$ & $0.80 \pm 0.19$ & $0.43 \pm 0.04$ \\
\hline Serum iron $(\mu \mathrm{mol} / \mathrm{l})$ & $73.50 \pm 3.85$ & $40.93 \pm 19.6$ & $45.10 \pm 5.26$ & $25.32 \pm 3.73$ & $42.27 \pm 11.3$ & $27.45 \pm 4.98$ \\
\hline
\end{tabular}

\subsection{Quantification of macrophages and T-cells in sciatic nerves}

Digitized pictures were taken with an LSM 510 Meta Confocal Microscope (Zeiss). The number of Iba-1 and/or ED1-positive macrophages and CD3-positive T-cells was counted in whole sciatic nerve cross sections ( $n=5$ in each group). Values represent numbers of stained cells per $\mathrm{mm}^{2}$.

\subsection{Transmission electron microscopy}

Mice ( $n=3$ per group) were perfused via the left heart ventricle, first with $250 \mathrm{ml}$ phosphate-buffered saline (PBS, pH 7.4, 37 ${ }^{\circ} \mathrm{C}$ ) containing $6250 \mu / 1$ heparin (Sigma, Taufkirchen, Germany), followed by $250 \mathrm{ml} \%$ glutaraldehyde with $1 \%$ paraformaldehyde in $0.1 \mathrm{M}$ PBS. Sciatic nerves were prepared and analyzed as described previously [32].

\subsection{Western blot}

Sciatic nerves ( $n=5$ per group) were lysed by ultrasonication in $60 \mathrm{mM}$ Tris- $\mathrm{HCl}, \mathrm{pH} 6.8$, containing $2 \%$ sodium dodecyl sulfate (SDS) and $10 \%$ sucrose. Tissue lysates were diluted 1:1 in sample buffer $(250 \mathrm{mM}$ Tris$\mathrm{HCl}, \mathrm{pH} 6.8$, containing $4 \%$ SDS, $10 \%$ glycerol, and $2 \%$ b-mercaptoethanol) and denatured at $95^{\circ} \mathrm{C}$ for $5 \mathrm{~min}$. Protein concentration was assessed with the bicinchoninic acid assay (BCA assay) protein assay (Pierbo Science, Bonn, Germany). Proteins (20 $\mu \mathrm{g}$ per lane) were separated by electrophoresis on a $12.5 \%$ or $15 \%$ SDS-polyacrylamide gel and transferred to nitrocellulose by electroblotting. Nonspecific binding sites were blocked with $5 \%$ dried milk powder for $45 \mathrm{~min}$. The blots were incubated with rabbit polyclonal anti-TNFa (ab 6671; 1:2000; Abcam, MA, USA) at $4^{\circ} \mathrm{C}$ overnight. Proteins were detected by incubating with horseradish peroxidase (HRP)-conjugated secondary antibodies at a 1:4,000 dilution; Dianova) at RT for $2 \mathrm{~h}$ and chemiluminescence kit (Amersham, Pharmacia, Freiburg, Germany). Integrated optical densities of the immunoreactive protein bands were measured with Gel Analyzer software (Media Cybernetics, Silver Spring, MD). Equal protein loading was verified using mouse anti-
D-glyceraldehyde-3-phosphate dehydrogenase antibody (GAPDH, Research Diagnostics, Flanders, The Netherlands; 1:3000).

\section{Results}

\subsection{Biochemical and physiological parameters}

In $o b / o b$ and $o b /+$ control mice, blood glucose concentrations analyzed between 8 a.m. and 9:30 a.m. were below $7 \mathrm{mmol} / \mathrm{l}$ and not significantly different between experimental groups (Table 1). In agreement with the previous studies [33,35], all $o b / o b$ animals were obese, exhibiting over $50 \%$ body fat and showing significantly higher levels of insulin, cholesterol, and lowdensity lipoprotein-cholesterol as compared to the $o b /+$ control mice. Triglyceride levels were higher only in $o b /$ $o b$ mice on standard and low iron diet as compared to the $o b /+$ control animals. Noteworthy, serum insulin concentrations were significantly lower in $o b / o b$ mice on the high iron diet as compared to the $o b / o b$ mice on the standard and low iron (Table 1).

Serum iron concentrations were significantly higher in all ob/ob animals than in the control groups. The highest serum iron concentration was found in $o b / o b$ mice on a high iron diet (Table 1).

\subsection{Nerve conduction studies}

We performed nerve conduction studies at the beginning and at the end of the experimental period. Sciatic nerve MNCVs of all ob/+ groups increased mildly throughout the experiment as expected with further maturation in control mice. Motor NCVs (MNCVs) of $o b / o b$ mice significantly declined with all iron diets (Figure 1(a and b)). When compared to the $o b /+$ control animals, sciatic MNCVs were reduced in $o b /$ $o b$ mice with different iron diets by up to $24 \%$ (Figure $1(\mathrm{e})$ ). This indicates that conduction was abnormally slowed rather than halted by a lack of further nerve maturation. The sciatic compound sensory NCVs (cSNCVs) were already by about $30 \%$ lower in all $o b$ / $o b$ mice at age 3 months before any dietary treatment started as compared to the $o b /+$ controls (Figure 1(c and d)). At the end of the study, the sciatic cSNCVs 

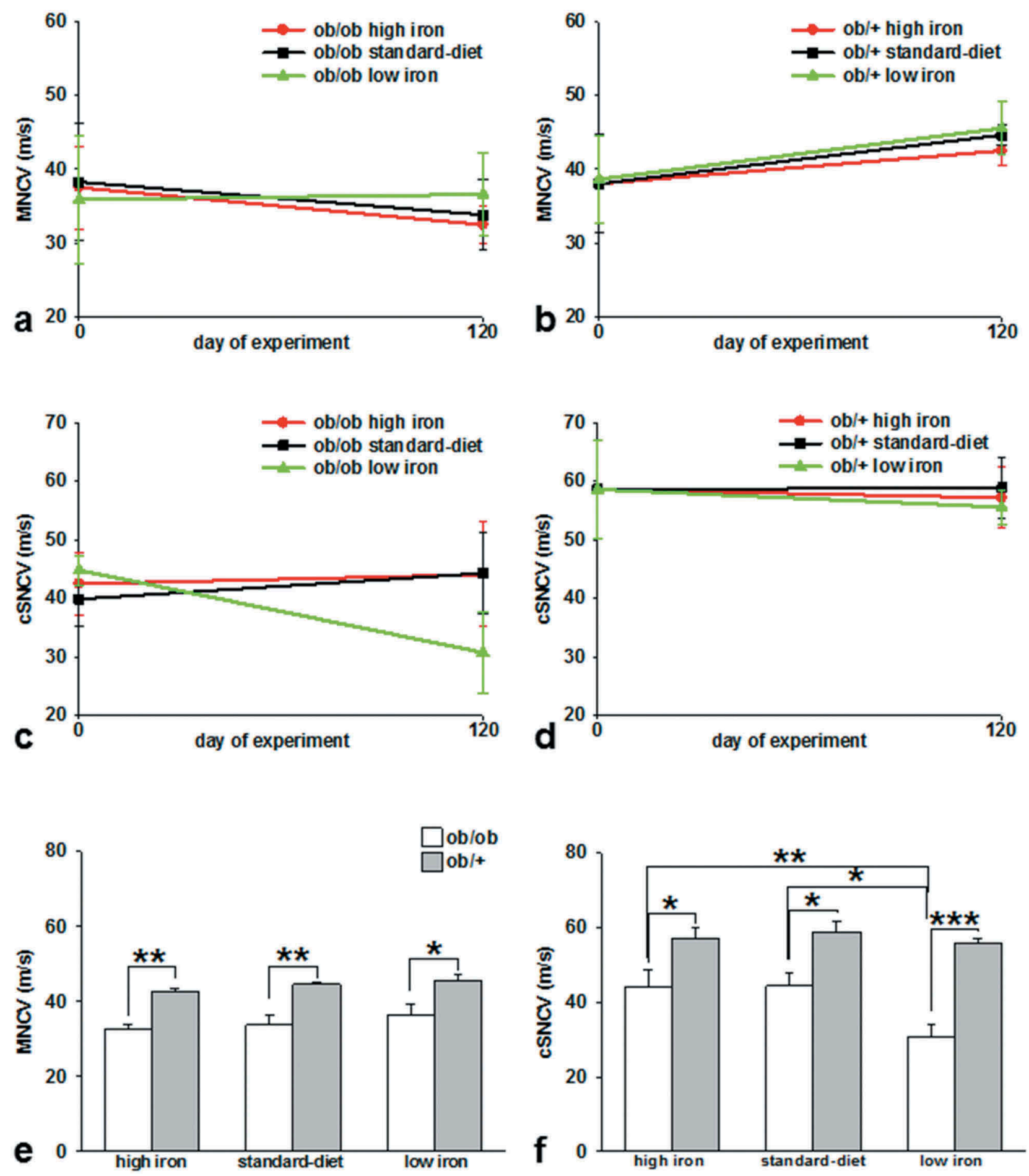

Figure 1. Nerve conduction studies. ( $a$ and b): The MNCV was decreasing in all $o b / o b$ mice (a) and increasing in all $o b /+$ control animals (b) throughout the experiment. ( $c$ and $d$ ): At the beginning of the experiment, the sciatic cSNCVs were significantly lower in all $o b / o b$ mice (c) compared to the $o b /+$ control ones (d) and it is decreasing in low iron ob/ob group throughout the experiment (c). (e and f): At the end of the experiment, the sciatic MNCVs were significantly reduced (by up to $24 \%$ ) in $o b / o b$ mice with different iron diets compared to the $o b /+$ control animals (e) and the sciatic cSNCVs were significantly decreased in all $o b / o b$ mice compared to the respective control animals (f). The highest CSNCV decrease (by up to 45\%) was observed in $o b / o b$ animals with a low iron diet compared to the other experimental groups (f). Values represent mean $\pm \operatorname{SEM}(n=4),{ }^{*} p<0.05$, ${ }^{* *} p<0.01,{ }^{* * *} p<0.001$, according to the one-way analysis of variance together with the Newman-Keuls test.

had significantly decreased in all ob/ob mice as compared to the respective control animals (Figure 1(f)). In contrast to $\mathrm{MNCV}$, the cSNCVs did not increase over the experimental period in the control mice. The highest cSNCV decrease (by up to 45\%) was observed in $o b / o b$ animals on a low iron diet (Figure 1(f)).

\subsection{Morphology of terminal skin fibers and sciatic nerves}

A significant degenerative loss of intraepidermal nerve fibers as terminal branches of the sensory fiber population of the sciatic nerve was observed in all $o b / o b$ mice 
as compared to the $o b /+$ control animals (Figure $2(\mathrm{a}-\mathrm{c})$ ) as expressed by a markedly reduced IENFD. This reduction was similar with high, standard, or low iron diet (Figure 2(c)).
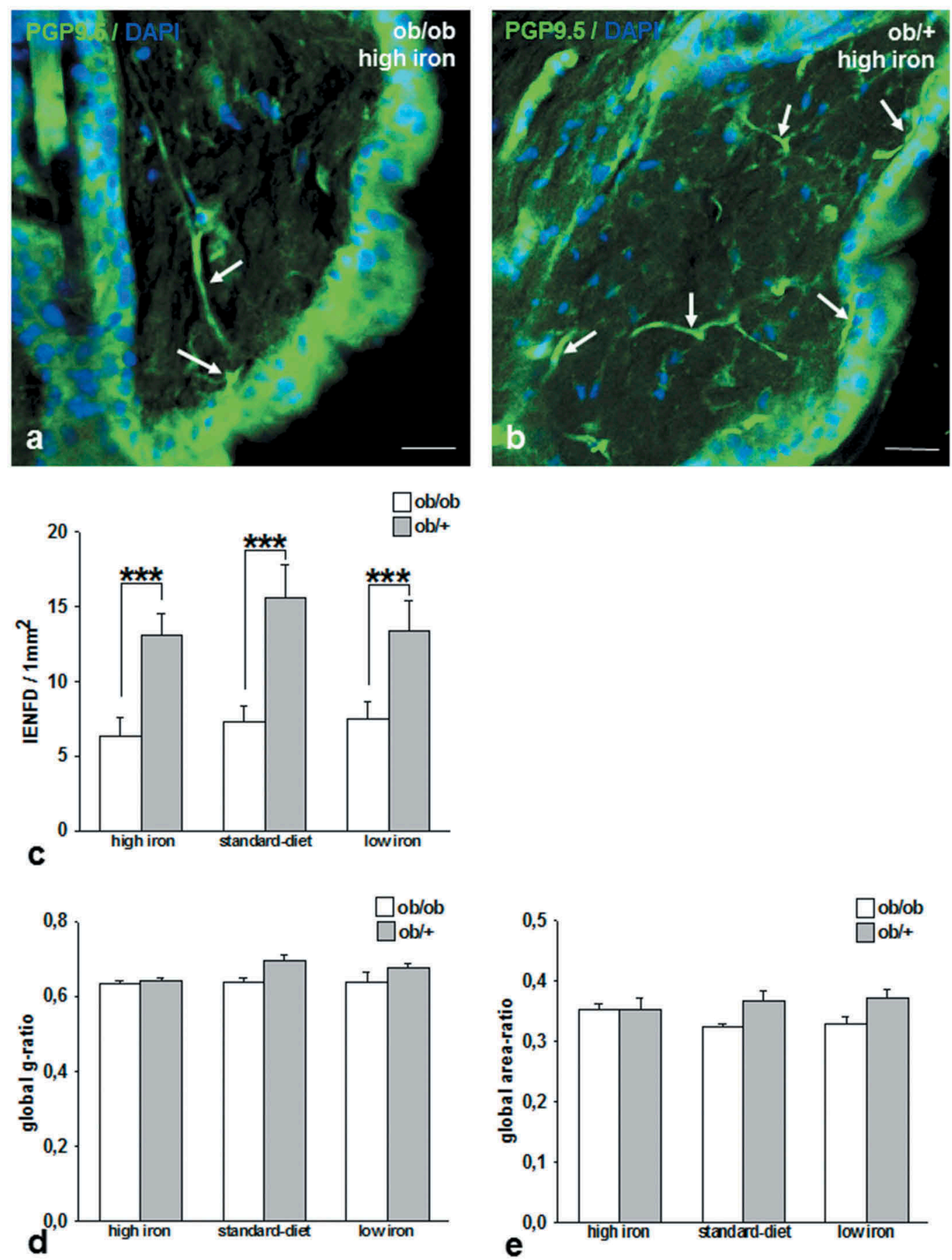

Semithin sections showed no obvious changes in fiber morphology with regard to the distribution of myelinated vs. unmyelinated fiber bundles. The thickness of the myelin sheath appeared similar across all

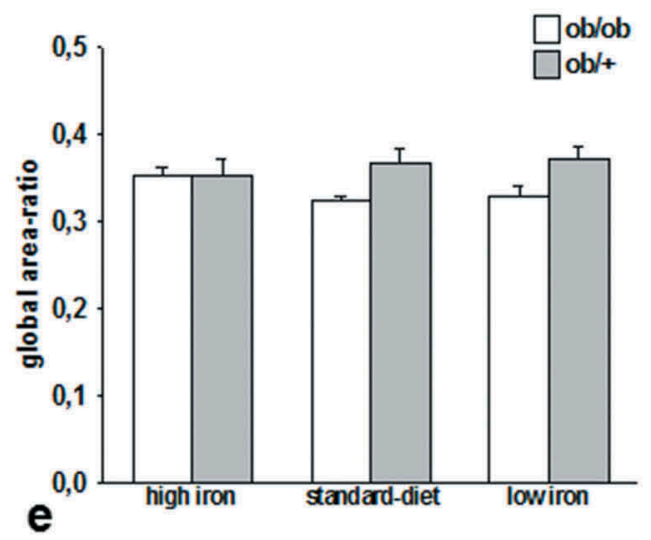

Figure 2. Morphology of sciatic nerve and its sensory fiber endings in the hindfoot skin of $o b / o b$ and $o b /+$ control mice fed with different iron diets. ( $a$ and b): Representative sections showing immunoreactivity (green) of PGF9.5-positive fibers (arrows). Nuclei are counterstained with DAPI (blue). Bars represent $20 \mu \mathrm{m}$. (c): Quantitative analysis of IENFD in the skin of the hindfoot in $o b / o b$ and $o b /+$ control animals. A significant loss of intraepidermal nerve fibers forming the terminal branches of sensory nerve components of the sciatic nerve was observed in all ob/ob mice compared to the $o b /+$ control animals. This reduction was similar with a high, standard, or low iron diet. ( $d$ and e): Sciatic nerves were examined for pathological changes by electron microscopy to determine the pathological changes in their structure and thickness of myelin sheath in relation to axon diameters expressed as fiber area-ratio and g-ratio. The global g-ratios (axon diameter/whole fiber diameter; (d) and the global area-ratios (axon area/whole fiber area; (e) were similar between experimental groups $(p>0.05)$. Values represent mean \pm SEM $(n=3),{ }^{*} p<0.05,{ }^{* *} p<0.01,{ }^{* * *} p<0.001$, according to the one-way analysis of variance together with the Newman-Keuls test. 
groups. Ultrathin sections of cross-sectioned nerve fibers allowed more detailed analyses. Here, no pathological changes of nerve fibers were found in mice of all dietary groups, neither in myelin sheaths nor in axons, and g-ratios (axon diameter/whole fiber diameter) and area-ratios (axon area/whole fiber area) also showed no difference between all experimental groups (Figure 2(d and e)).

\subsection{Inflammatory cells and TNF-alfa expression in sciatic nerves}

Several previous studies suggest a role for obesity and lipid-induced inflammation in the development of PN [3]. The number of Iba-1-positive macrophages and T-cells was increased by about $95 \%$ up to almost $150 \%$ in $o b / o b$ mice as compared to the respective lean control animals (Figures 3-6). Overall, the inflammatory cell numbers were markedly and significantly higher in sciatic nerves of $o b / o b$ mice on a low iron diet as compared to $o b / o b$ and $o b /+$ mice on standard or high iron diet (Figures 3 and 6). With double-immunofluorescence staining, we identified co-localization of ED1 (CD68) for activated macrophages with Iba-1-positive macrophages (Figure 5). Noteworthy, the highest number of Iba-1-/ED1-positive cells (39\%) was found in $o b / o b$ mice with the low iron diet as compared to the other experimental groups indicating the highest pro-inflammatory milieu in this dietary group (Figure 3(a)).

To corroborate these findings, we tested the protein expression of the prime pro-inflammatory cytokine $\mathrm{TNF} \alpha$. Indeed, $\mathrm{TNF} \alpha$ protein expression was increased up to fivefold in $o b / o b$ mice with iron low diet and least with high iron diet (Figure 7).

\section{Discussion}

The principal results of our study are intraepidermal nerve fiber degeneration in the foot skin and functional abnormalities of the sensory component in the sciatic nerve associated with low-grade macrophage and T-cell infiltration and TNFa activation in sciatic nerve in $o b / o b$ mice. This pattern of peripheral nerve pathology could be augmented by a partial iron deprivation induced by low dietary iron intake, while a high iron diet was an ameliorating factor. Pathogenetically relevant mild inflammatory activity has first been described in heredodegenerative PNS disorders such as Charcot-MarieTooth disease and its various mouse models [39-41].

It is widely accepted that a major increase in adipose mass contributes to adipose tissue dysfunction and promotes metabolic disorders via a mild, chronic inflammation which is characterized by increased expression of pro-inflammatory factors including TNFa $[3,42,43]$. Our findings of a mild peripheral nerve dysfunction with more marked distal axon degeneration lead us to suggest that the inflammatory milieu as expressed by mononuclear cells and autocrine cytokines may be a pivotal pathogenic process contributing to $\mathrm{PN}$. TNFa may be secreted by these intraneural inflammatory cells or by cells in adipose tissue and can alter and penetrate the blood-nerve barrier exerting neurotoxic tissue effects and attracting further immunocompetent white cells such as macrophages and T-cells into the endoneurial nerve compartment. This type of mechanism was first suggested by our earlier work in the STZ-diabetes model. As now shown here and also suggested from work by other groups, all this may happen in the absence of hyperglycemia $[3,43-$ 45]. This could, in turn, lead a pro-inflammatory vicious circle via $\mathrm{TNF} \alpha$-induced sensitization of sensory neurons potentially augmented by an array of other cytokines and chemokines [46]. An important effect of this immune activation is an increased release of further pro-inflammatory factors at peripheral nerve terminals [47].

The second important finding of this study is that this pathologic mechanism can collectively be modulated by non-heme iron. The increased number of pro-inflammatory cells together with a markedly augmented TNFa protein expression in the low iron diet fed $o b / o b$ mice suggests a pro-inflammatory role of dietary deprivation of non-heme iron.

How this effect of iron deprivation may be related to iron metabolism in obesity and MetS is a crucial but not yet answered question. Recently, it has been shown that obesity alters adipose tissue macrophage iron content and tissue iron distribution [48]. Highfat diet feeding increased the absolute number of adipose tissue macrophages. This increase was driven by a dramatic accumulation of macrophages with low iron content, which displayed decreased gene expression of anti-inflammatory factors and increased expression of pro-inflammatory mediators [48]. There were also macrophages described with high iron content exhibiting a pro-inflammatory shift. Impaired iron handling of macrophages with high iron content coincided with adipocyte iron accumulation and hepatic iron deficiency [48]. To the best of our knowledge, there are few, if any, studies concerning the modulatory role of nonheme iron in human peripheral neuropathies potentially acting through low-grade nerve inflammation. Previously, we have shown an increased number of activated macrophages and T-cells in sciatic nerves of STZ-rats with overt hyperglycemia as in type 1 diabetes [32]. In this study, the highest number of pro-inflammatory cells was observed in the sciatic nerves of animals with low iron intake [32]. From the present data, it becomes obvious that the modulatory role of iron intake on peripheral nerve pathology is not dependent on the co-existence of hyperglycemia suggesting a blood glucose- 

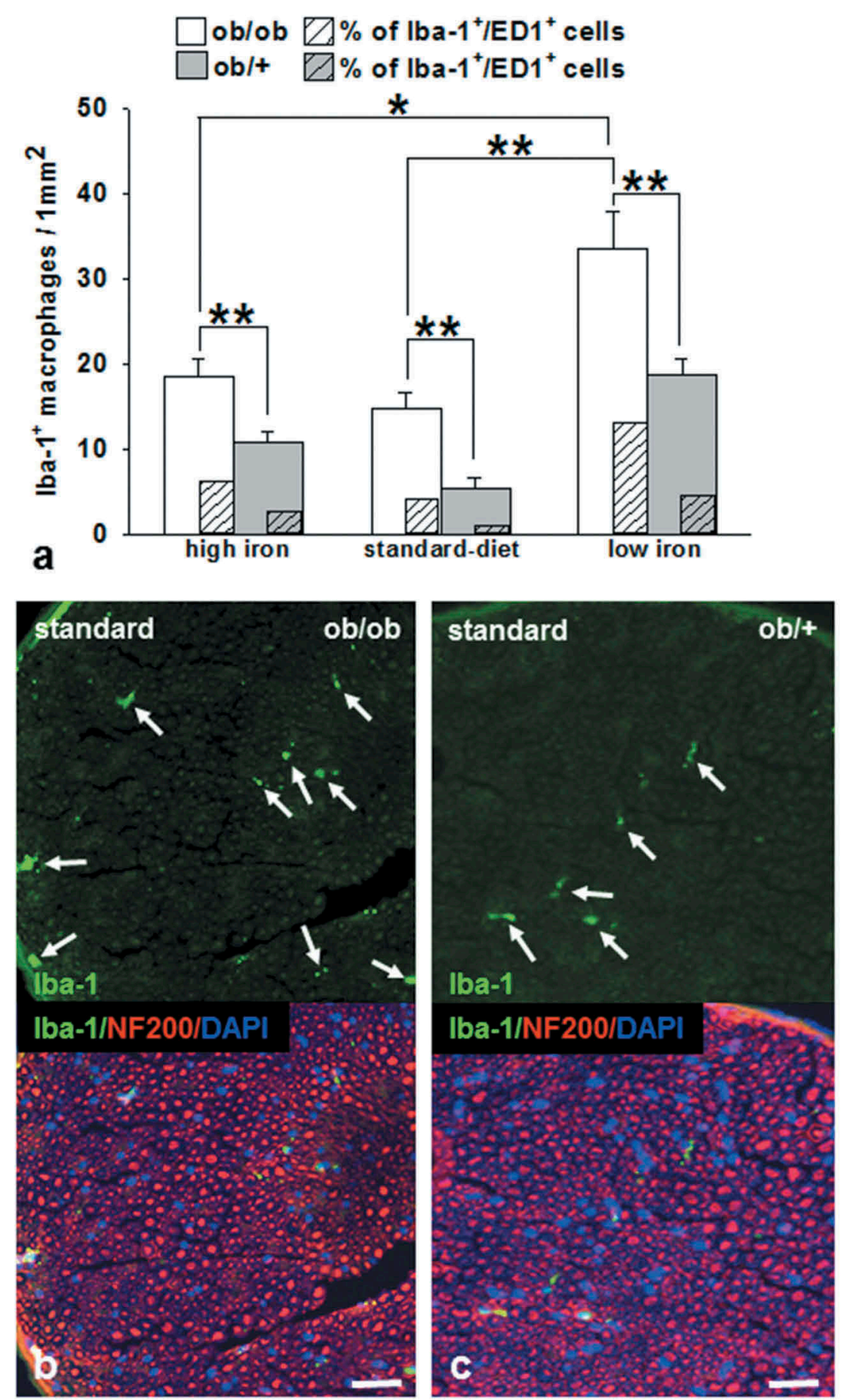

Figure 3. Macrophage infiltration and distribution in the sciatic nerve of $o b / o b$ and $o b /+$ control mice fed with different iron diets. (a): Quantitative analysis of macrophage infiltration in sciatic nerves of $o b / o b$ and $o b /+$ control mice. Values represent means $\pm S E M(n=5)$, ${ }^{*} p<0.05,{ }^{* *} p<0.01$, according to the one-way analysis of variance together with the Newman-Keuls test. Percent values of activated (CD68- and lba-1-positive) and total macrophages (Iba-1-positive) as a composite evaluation: $6 \%$ in ob/ob mice vs. $3 \%$ in ob/+ mice on the high iron diet; $4 \%$ in ob/ob mice vs. $1 \%$ in ob/+ mice on the standard iron diet; and $13 \%$ in ob/ob mice vs. $5 \%$ in $o b /+$ mice on the low iron diet. (b and c): Double immunofluorescence staining for lba-1-positive macrophages (in green, upper panel, white arrows) and for neurofilament 200-positive nerve fibers (in red, lower panel) in the sciatic nerve of standard iron diet $o b / o b$ and $o b /+$ control mice. Nuclei are counterstained with DAPI (in blue). Bars represent $100 \mu \mathrm{m}$.

independent mechanism in obesity and MetS. In accordance with our findings, it has recently been shown that iron significantly reduces proinflammatory polarization of macrophages and, in turn, decreases the production and secretion of proinflammatory cytokines [49].

Another consequence of chronic adipose tissue inflammation in obese individuals is impaired insulin signaling and compromised triglyceride storage [3]. Cooksey and co-workers (2010) have shown that dietary iron restriction or iron chelation protect from loss of $\beta$-cell function and diabetes in obese $o b / o b$ mice [20]. In contrast to these observations, we here demonstrate that insulin and triglyceride levels were significantly lower in $o b / o b$ mice with high iron diet than with standard and low-iron-fed $o b / o b$ mice. The obtained 

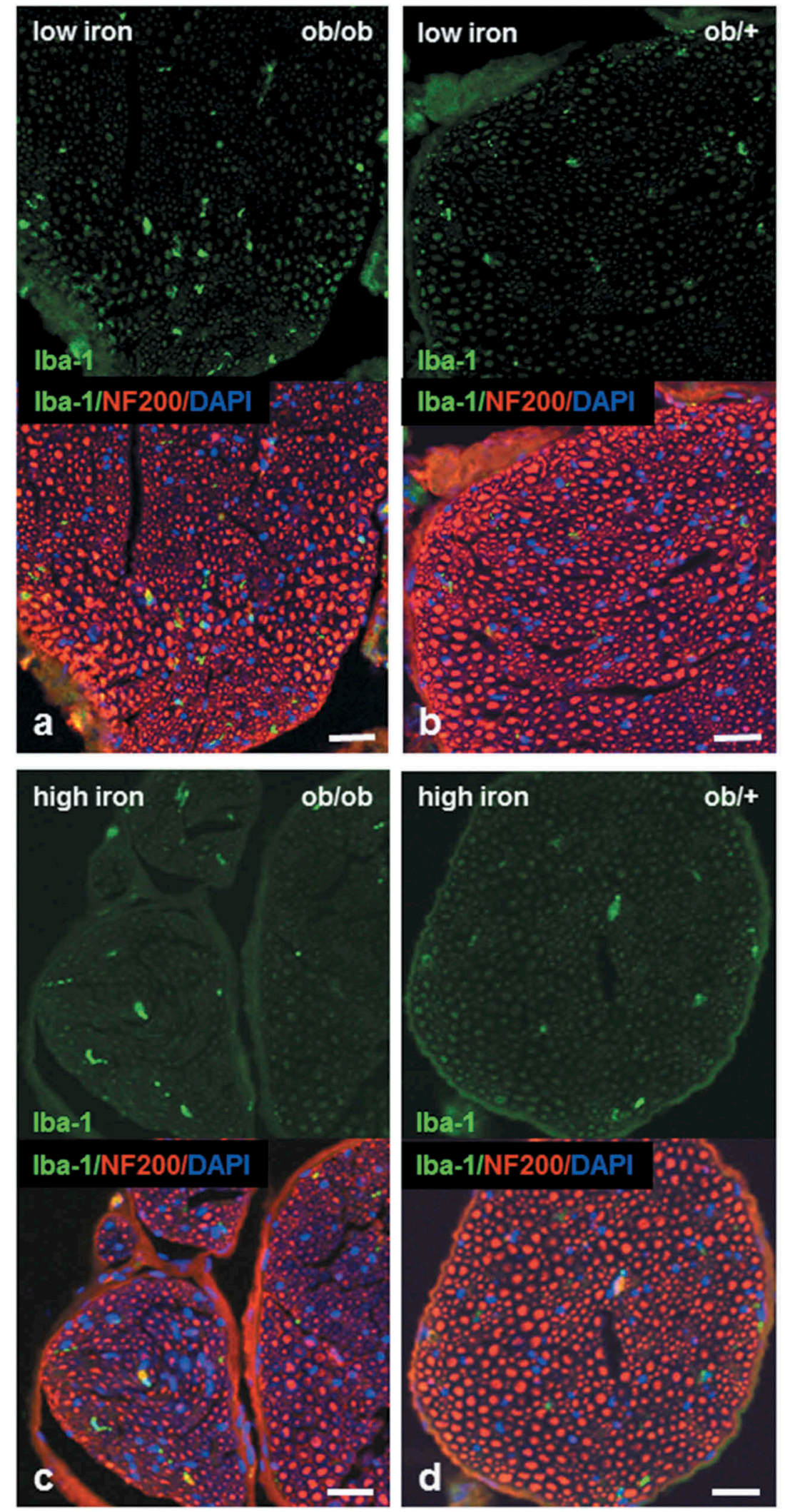

Figure 4. Double immunofluorescence staining for lba-1-positive macrophages (in green, upper panel) and for neurofilament 200-positive nerve fibers (in red, lower panel) in the sciatic nerve of low iron diet ob/ob (a) and ob/+ control (b) mice as well as high iron diet $o b / o b$ (c) and $o b /+$ control (d) mice. Nuclei are counterstained with DAPI (in blue). Bars represent $100 \mu \mathrm{m}$.

results suggest the improvement of insulin sensitivity in this mouse group. In the study by Cooksey et al. [20], mice had hyperglycemia and were fed with a highcarbohydrate or high-fat diet with different iron content. The high-carbohydrate or the high-fat diets could be additional factors that may have influenced insulin and glucose metabolism and $\beta$-cell function of investigated $o b / o b$ mice [20]. Bao et al. (2012) have summarized in a meta-analysis of prospective human studies that there are no significant correlations between 

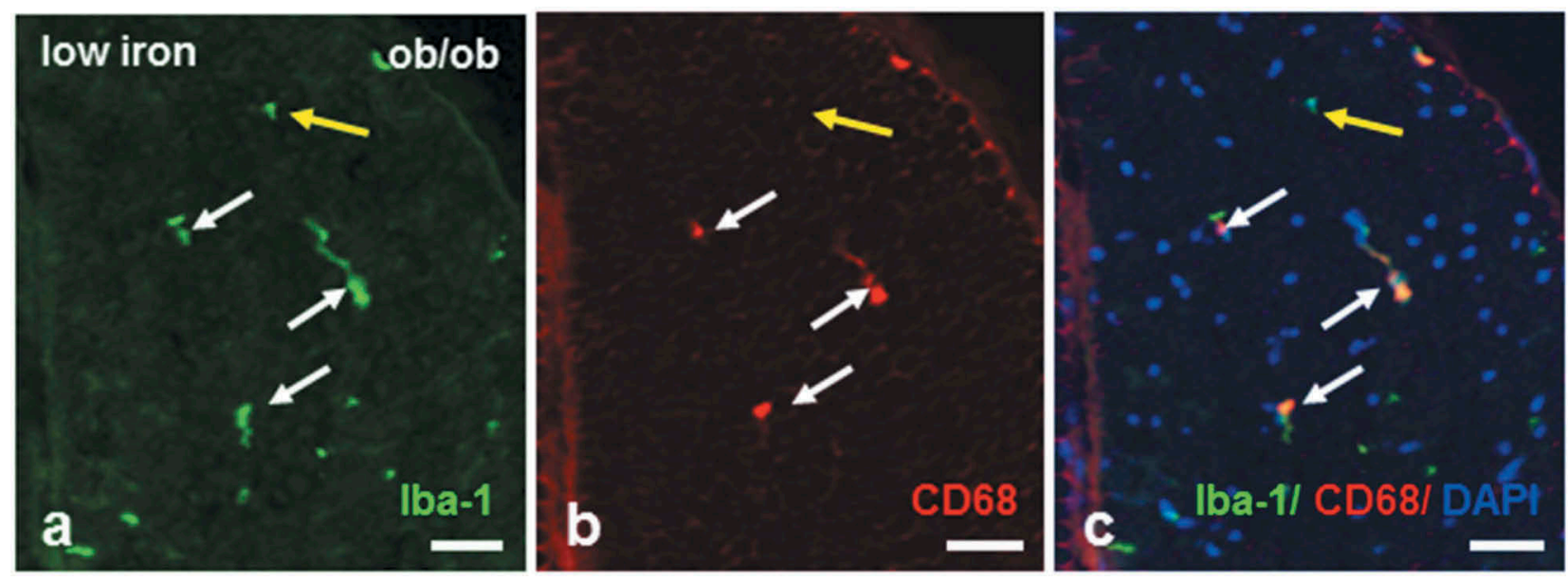

Figure 5. Double immunofluorescence staining for lba-1-positive (in green; a) and for CD68-positive (in red; b) macrophages and colocalization of both proteins $(c)$ in the sciatic nerve of $o b / o b$ mouse fed with low iron diet. White arrows show activated (CD68- and Iba-1-positive) macrophages and the yellow arrow show inactive (only lba-1-positive) macrophage. Bars represent $30 \mu \mathrm{m}$.
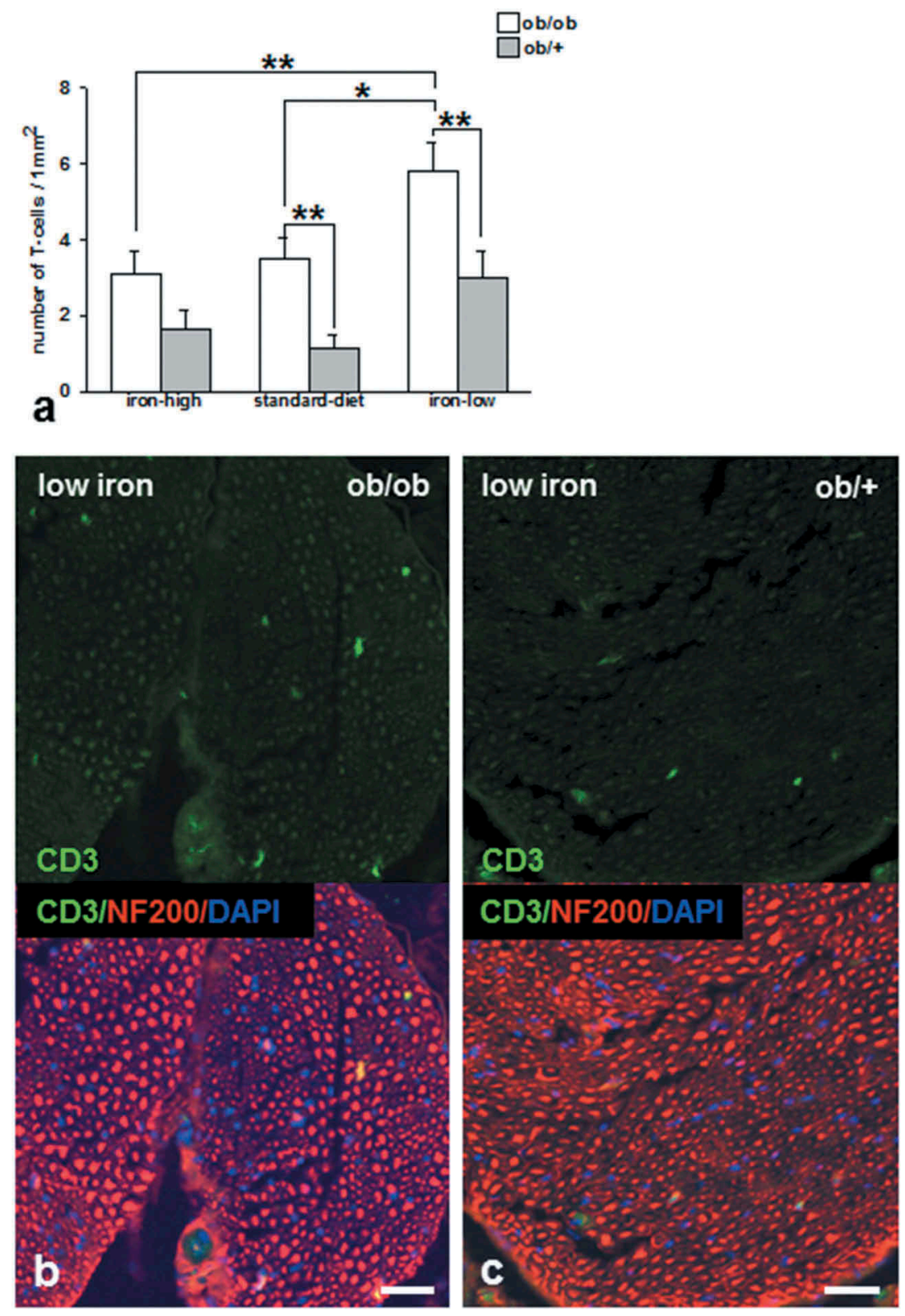

Figure 6. (a): Quantitative analysis of T-cell infiltration in sciatic nerves of $o b / o b$ and $o b /+$ control mice fed with different iron diets. Values represent means $\pm \operatorname{SEM}(n=5),{ }^{*} p<0.05,{ }^{* *} p<0.01$, according to the one-way analysis of variance together with the Newman-Keuls test. ( $b$ and c): Double immunofluorescence staining for CD3-positive T-cells (in green, upper panel) and for neurofilament 200-positive nerve fibers (in red, lower panel). Nuclei are counterstained with DAPI (in blue). Bars represent $100 \mu \mathrm{m}$. 


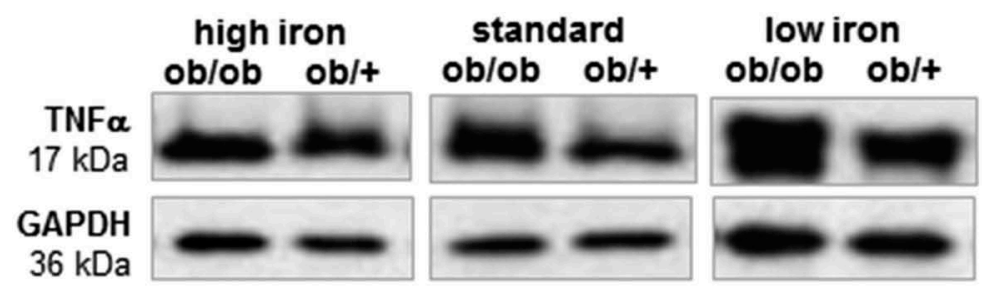

a

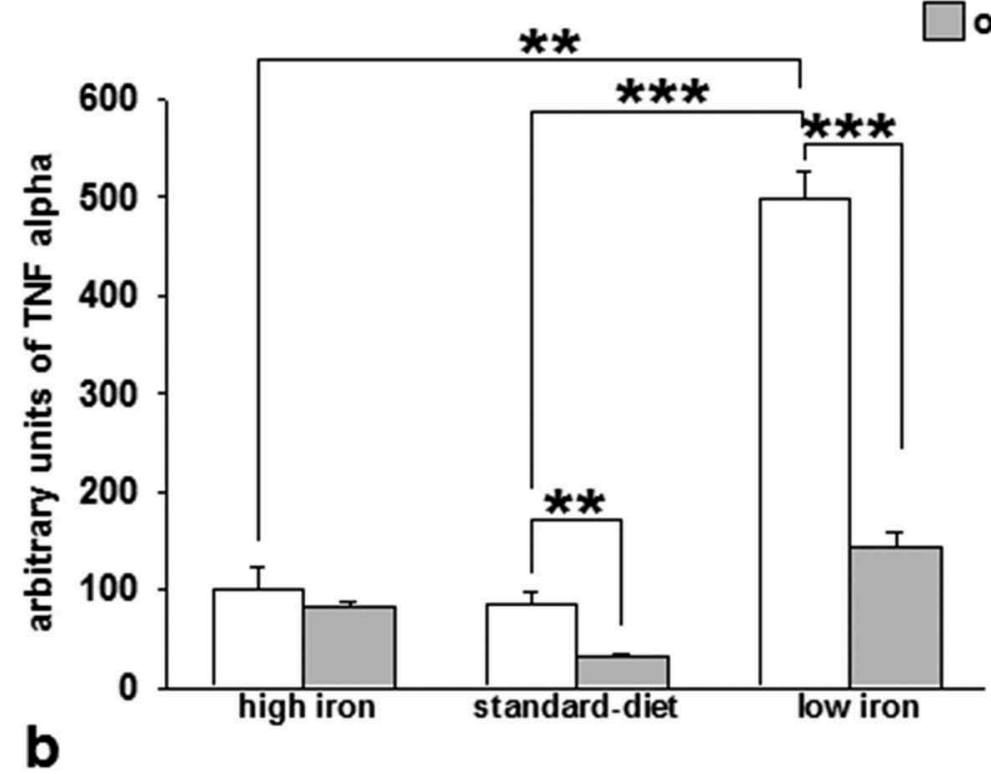

Figure 7. Effect of different iron diets on TNFa protein expression in sciatic nerves of $o b / o b$ and $o b /+$ control mice. TNFa protein expression was markedly increased (up to fivefold) in $o b / o b$ mice with low iron diet as compared with the other experimental groups. (a): Representative Western blot and (b) data of densitometrical analysis after normalization to GAPDH. Values represent mean \pm SEM $(n=5),{ }^{* *} p<0.01,{ }^{* * *} p<0.001$, according to the one-way analysis of variance together with the Newman-Keuls test.

dietary intake of total iron, non-heme, and supplemental iron with the risk of developing T2D [50]. The observed improvement of insulin signaling could have led to a decrease in the pro-inflammatory status and, in turn, to a better peripheral nerve function.

Collectively, we found a functionally relevant increase in peripheral nerve pathology with chronic iron depletion rather than with iron overload. We propose that the effects of iron may be of a wider pathogenetic relevance than hitherto accepted. Our data support the concept of potentially relevant inflammatory features that exist independent of the presence or absence of hyperglycemia in disorders associated with obesity. Since our experiments lasted only 4 months, while in human obesity and MetS PN is a very late consequence, future mouse experiments should focus on the long-term effects of obesity and MetS and of the role of iron metabolism at later time points. Once it can be confirmed that very late effects are even more pronounced than shown in the present study, the time has come to develop new therapeutic strategies halting nerve pathology and inflammation and to plan clinical trials.

\section{Acknowledgments}

We thank J. Craatz, A. Ehrlich, and C. Merkwitz for excellent technical assistance.

\section{Disclosure statement}

No potential conflict of interest was reported by the authors.

\section{Ethical Publication Statement}

We confirm that we have read the Journal's position on issues involved in ethical publication and affirm that this report is consistent with those guidelines.

\section{Funding}

This work was funded by the Deutsche Forschungsgemeinschaft, SFB1052: B1 (to MB) and B4 (to NK); German Diabetes Center 82DZD00601 (NK); and Federal Ministry of Education and Research (BMBF), Germany FKZ: 01E01501 (NK). KVT is funded by a Senior Research Professorship grant by the University of Würzburg. 


\section{Notes on contributors}

Joanna Kosacka is a scientist at the Institute of Anatomy and at the Department of Neurology of the University of Leipzig. She has recently researched new factors accelerating peripheral nerve regeneration and the role of inflammation and angiogenesis in peripheral neuropathies. She was the main investigator of the research group, which found Ang-1 as a novel neurotrophic factor. She is also actively involved in other neuroscience and endocrinology studies. She is interested in pathological changes of peripheral nerves as well as in new therapies of peripheral neuropathy in type 1 and 2 diabetic and obese subjects.

Katrin Woidt is a licensed medical doctor. For one year she works at the emergency surgery station in a local clinic. At the Institute of Anatomy, University of Leipzig, she has carried out a doctoral thesis on peripheral neuropathy in animal models of obesity and metabolic syndrome.

Klaus Viktor Toyka is a neurologist and university lecturer. The focus of his research lies in the investigation of disease models of neuroimmunological and degenerative diseases in mice and rats, in connection with questions of humoral and cell-mediated immunopathogenesis and the development of new, mostly molecular therapeutic strategies. These research results are the basis for therapy research in humans. His most important findings include the pathogenic significance of autoantibodies in myasthenia, multiple forms of polyneuritis, multiple sclerosis, paraneoplastic diseases and their therapy, as well as the mechanisms of lesion formation in these diseases.

Sabine Paeschke studied nutrition sciences. Since 2016, she is a $\mathrm{PhD}$ student at the Institute of Anatomy, University of Leipzig. Her research concerns the mechanisms of neuropathy in patients with obesity and glucose metabolism disorders.

Nora Klöting is the head of the adiposity research group of Integrated Research and Treatment Center (IFB) Adiposity Disease, Leipzig, Germany. She is interested in the role of innate immune system on obesity-related inflammation in adipose tissue. She established a new congenic mouse, with an exchanged major histocompatibility complex (MHC, H2 region) region between obesity-resistant 129S6/SvEvTac and obesity-prone C57BL/6 mice. The new constructed congenic line, BL6.MHC129, will give the possibility to analyse the role of innate immune system on obesityinduced inflammation in adipose tissue and obesity related traits.

Ingo Bechmann is a neurologist and university lecturer and since 2009 he is the head of the Institute of Anatomy, University of Leipzig in Germany. He researches mechanisms of immunological tolerance in the brain in diseases such as multiple sclerosis and Alzheimer's disease. He discovered under what conditions immune cells are "called" into the brain and how they are deactivated by local immunosuppressive mechanisms. In order to be able to directly observe tissue reactions he developed cut culture models of human tissues that better map the mechanisms in the treatment of cancer cells than animal experiments.

Matthias Blüher is an endocrinologist and professor at the University Hospital Leipzig. He is mainly concerned with morbid overweight (obesity), adipokinetic hormones, insulin resistance and diabetes (type 2 diabetes mellitus). He is universally recognized as an authority on subject of metabolic disorders especially in human patients with obesity or/and type 2 diabetes.

Joachim Thiery is a specialist in laboratory medicine. The scientific focus of Joachim Thiery is on the field of lipid metabolism and the pathophysiology of lipids in cardiovascular diseases, especially arteriosclerosis. His work covers a broad range of methods, ranging from experimental studies on the development of new biomarkers, in particular by mass spectrometry, to clinical trials. He researches the genetic causes of arteriosclerosis and lipid metabolism, carries out metabolome analyses and genome-wide association studies in metabolic and vascular diseases and develops therapy concepts and biomarkers for the prevention of vascular diseases and lipid metabolism disorders.

Susann Ossmann works as a veterinary assistant at the Heart Centre of University of Leipzig. She coordinates animal experiments.

Petra Baum works at the Department of Neurology, University of Leipzig, Germany. She is the assistant medical director (leitende Oberärztin) of the Department of Neurology and specialized in clinical neuroelectrophysiology. She is interested in pathological changes of peripheral nerves as well as in new therapies of peripheral neuropathy in type 1 and 2 diabetic as well as obese subjects.

Marcin Nowicki is veterinary surgeon by training with specialty in laboratory animal research. In 2004, Marcin Nowicki joined the Institute of Anatomy in Leipzig with the aim to continue his academic career in Anatomy and neuroscience. It is a strong intention of Marcin Nowicki to combine teaching and science. He has recently researched new factors accelerating peripheral nerve regeneration and the role of oxidative stress, iron and oxidized lipoproteins in development of peripheral diabetic neuropathy.

\section{Author contributions}

Conceived and designed the experiments: JK, KW, MN, and PB. Performed the experiments: JK, KW, SP, SO, MN, and PB. Analyzed the data: JK, KW, KVT, IB, MN, and PB. Contributed reagents/materials/analysis tools: NK, IB, JT, and $\mathrm{PB}$. Wrote and edited the manuscript: JK, $\mathrm{KW}, \mathrm{MN}$, $\mathrm{KVT}$, and PB.

\section{References}

[1] Jung UJ, Choi MS. Obesity and its metabolic complications: the role of adipokines and the relationship between obesity, inflammation, insulin resistance, dyslipidemia and nonalcoholic fatty liver disease. Int J Mol Sci. 2014;15(4):6184-6223.

[2] Callaghan BC, Xia R, Reynolds E, et al. Association between metabolic syndrome components and polyneuropathy in an obese population. JAMA Neurol. 2016;73(12):1468-1476.

[3] O’Brien PD, Hinder LM, Callaghan BC, et al. Neurological consequences of obesity. Lancet Neurol. 2017;16(6):465-477.

[4] Herman RM, Brower JB, Stoddard DG, et al. Prevalence of somatic small fiber neuropathy in obesity. Int J Obesity. 2007;31(2):226-235. 
[5] Pop-Busui R, Boulton AJ, Feldman EL, et al. Diabetic neuropathy: a position statement by the American Diabetes Association. Diabetes Care. 2017;40(1):136-154.

[6] Callaghan B, Feldman E. The metabolic syndrome and neuropathy: therapeutic challenges and opportunities. Ann Neurol. 2013;74(3):397-403.

[7] Kennedy JM, Zochodne DW. Impaired peripheral nerve regeneration in diabetes mellitus. J Peripher Nerv Syst: JPNS. 2005;10(2):144-157.

[8] Said G. Diabetic neuropathy - a review. Nat Clin Pract Neurol. 2007;3(6):331-340.

[9] Hozumi J, Sumitani M, Matsubayashi Y, et al. Relationship between neuropathic pain and obesity. Pain Res Manag. 2016;2016:2487924.

[10] Cameron NE, Cotter MA. Effects of an extracellular metal chelator on neurovascular function in diabetic rats. Diabetologia. 2001;44(5):621-628.

[11] Dyck PJ, Giannini C. Pathologic alterations in the diabetic neuropathies of humans: a review. J Neuropathol Exp Neurol. 1996;55(12):1181-1193.

[12] Kosacka J, Nowicki M, Kloting N, et al. COMPangiopoietin-1 recovers molecular biomarkers of neuropathy and improves vascularisation in sciatic nerve of ob/ob mice. PloS one. 2012;7(3):e32881.

[13] Nowicki M, Kosacka J, Serke H, et al. Altered sciatic nerve fiber morphology and endoneural microvessels in mouse models relevant for obesity, peripheral diabetic polyneuropathy, and the metabolic syndrome. J Neurosci Res. 2012;90(1):122-131.

[14] Tesfaye S, Selvarajah D. Advances in the epidemiology, pathogenesis and management of diabetic peripheral neuropathy. Diabetes Metab Res Rev. 2012;28 (Suppl 1):8-14.

[15] Callaghan BC, Xia R, Banerjee M, et al., Health ABCS. Metabolic syndrome components are associated with symptomatic polyneuropathy independent of glycemic status. Diabetes Care. 2016;39(5):801-807.

[16] Baum P, Petroff D, Classen J, et al. Dysfunction of autonomic nervous system in childhood obesity: a cross-sectional study. PloS one. 2013;8(1):e54546.

[17] Hubler MJ, Peterson KR, Hasty AH. Iron homeostasis: a new job for macrophages in adipose tissue? Trends Endocrinol Metab. 2015;26(2):101-109.

[18] Aigner E, Feldman A, Datz C. Obesity as an emerging risk factor for iron deficiency. Nutrients. 2014;6 (9):3587-3600.

[19] Aso Y, Takebayashi K, Wakabayashi S, et al. Relation between serum high molecular weight adiponectin and serum ferritin or prohepcidin in patients with type 2 diabetes. Diabetes Res Clin Pract. 2010;90 (3):250-255.

[20] Cooksey RC, Jones D, Gabrielsen S, et al. Dietary iron restriction or iron chelation protects from diabetes and loss of beta-cell function in the obese (ob/ ob lep-/-) mouse. Am J Physiol Endocrinol Metab. 2010;298(6):E1236-1243.

[21] Kim CH, Kim HK, Bae SJ, et al. Association of elevated serum ferritin concentration with insulin resistance and impaired glucose metabolism in Korean men and women. Metabolism. 2011;60(3):414-420.

[22] Le Blanc S, Villarroel P, Candia V, et al. Type 2 diabetic patients and their offspring show altered parameters of iron status, oxidative stress and genes related to mitochondrial activity. Biometals. 2012;25(4):725-735.

[23] Levi S, Taveggia C. Iron homeostasis in peripheral nervous system, still a black box? Antioxid Redox Signal. 2014;21(4):634-648.

[24] Stroh M, Swerdlow RH, Zhu H. Common defects of mitochondria and iron in neurodegeneration and diabetes (MIND): a paradigm worth exploring. Biochem Pharmacol. 2014;88(4):573-583.

[25] Wrede CE, Buettner R, Bollheimer LC, et al. Association between serum ferritin and the insulin resistance syndrome in a representative population. Eur J Endocrinol. 2006;154(2):333-340.

[26] Huang X. Iron overload and its association with cancer risk in humans: evidence for iron as a carcinogenic metal. Mutat Res. 2003;533(1-2):153-171.

[27] Emerit J, Beaumont C, Trivin F. Iron metabolism, free radicals, and oxidative injury. Biomed Pharmacothe. 2001;55(6):333-339.

[28] Papanikolaou G, Pantopoulos K. Iron metabolism and toxicity. Toxicol Appl Pharmacol. 2005;202(2):199-211.

[29] Hentze MW, Muckenthaler MU, Galy B, et al. Two to tango: regulation of mammalian iron metabolism. Cell. 2010;142(1):24-38.

[30] Lee DW, Andersen JK, Kaur D. Iron dysregulation and neurodegeneration: the molecular connection. Mol Interv. 2006;6(2):89-97.

[31] Urrutia PJ, Mena NP, Nunez MT. The interplay between iron accumulation, mitochondrial dysfunction, and inflammation during the execution step of neurodegenerative disorders. Front Pharmacol. 2014;5:38.

[32] Baum P, Kosacka J, Estrela-Lopis I, et al. The role of nerve inflammation and exogenous iron load in experimental peripheral diabetic neuropathy (PDN). Metabolism. 2016;65(4):391-405.

[33] Drel VR, Mashtalir N, Ilnytska O, et al. The leptindeficient (ob/ob) mouse: a new animal model of peripheral neuropathy of type 2 diabetes and obesity. Diabetes. 2006;55(12):3335-3343.

[34] O’Brien PD, Hur J, Hayes JM, et al. BTBR ob/ob mice as a novel diabetic neuropathy model: neurological characterization and gene expression analyses. Neurobiol Dis. 2015;73:348-355.

[35] Haluzik M, Colombo C, Gavrilova O, et al. Genetic background (C57BL/6J versus FVB/N) strongly influences the severity of diabetes and insulin resistance in ob/ob mice. Endocrinology. 2004;145(7):3258-3264.

[36] Nowicki M, Baum P, Kosacka J, et al. Effects of isoflurane anesthesia on F-waves in the sciatic nerve of the adult rat. Muscle Nerve. 2014;50(2):257-261.

[37] Krieger F, Elflein N, Saenger S, et al. Polyethylene glycol-coupled IGF1 delays motor function defects in a mouse model of spinal muscular atrophy with respiratory distress type 1. Brain. 2014;137(Pt 5):1374-1393.

[38] Kosacka J, Nowicki $M$, Bluher $M$, et al. Increased autophagy in peripheral nerves may protect Wistar Ottawa Karlsburg W rats against neuropathy. Exp Neurol. 2013;250:125-135.

[39] Carenini S, Maurer M, Werner A, et al. The role of macrophages in demyelinating peripheral nervous system of mice heterozygously deficient in p0. J Cell Biol. 2001;152(2):301-308. 
[40] Martini R, Toyka KV. Immune-mediated components of hereditary demyelinating neuropathies: lessons from animal models and patients. Lancet Neurol. 2004;3(8):457-465.

[41] Klein D, Patzko A, Schreiber D, et al. Targeting the colony stimulating factor 1 receptor alleviates two forms of Charcot-Marie-Tooth disease in mice. Brain. 2015;138(Pt 11):3193-3205.

[42] Hotamisligil GS, Shargill NS, Spiegelman BM. Adipose expression of tumor necrosis factor-alpha: direct role in obesity-linked insulin resistance. Science. 1993;259(5091):87-91.

[43] Anstey KJ, Cherbuin N, Budge M, et al. Body mass index in midlife and late-life as a risk factor for dementia: a meta-analysis of prospective studies. Obes Rev. 2011;12(5):e426-437.

[44] Hur J, Dauch JR, Hinder LM, et al. The metabolic syndrome and microvascular complications in a murine model of type 2 diabetes. Diabetes. 2015;64(9):3294-3304.
[45] Lupachyk S, Watcho P, Hasanova N, et al. Triglyceride, nonesterified fatty acids, and prediabetic neuropathy: role for oxidative-nitrosative stress. Free Radic Biol Med. 2012;52(8):1255-1263.

[46] Miller RJ, Jung H, Bhangoo SK, et al. Cytokine and chemokine regulation of sensory neuron function. Handb Exp Pharmacol. 2009;194:417-449.

[47] Chiu IM, von Hehn CA, Woolf CJ. Neurogenic inflammation and the peripheral nervous system in host defense and immunopathology. Nat Neurosci. 2012;15 (8):1063-1067.

[48] Orr JS, Kennedy A, Anderson-Baucum EK, et al. Obesity alters adipose tissue macrophage iron content and tissue iron distribution. Diabetes. 2014;63(2):421-432.

[49] Gan ZS, Wang QQ, Li JH, et al. Iron reduces M1 macrophage polarization in RAW264.7 macrophages associated with inhibition of STAT1. Mediators Inflamm. 2017;2017:8570818.

[50] Bao W, Rong Y, Rong S, et al. Dietary iron intake, body iron stores, and the risk of type 2 diabetes: a systematic review and meta-analysis. BMC Med. 2012;10:119. 


\section{Zusammenfassung}

Dissertation zur Erlangung des akademischen Grades

Dr. med.

Titel

„Der Einfluss des Eisenstoffwechsels und die Rolle der peripheren nervalen Inflammation in der Entwicklung der peripheren Neuropathie bei adipösen nichtdiabetischen leptindefizienten $o b / o b$ - Mäusen“

Eingereicht von

Katrin Woidt

Angefertigt an/ in

Universität Leipzig/ Institut für Anatomie

Betreut von

PD Dr. Marcin Nowicki

eingereicht

Die periphere Neuropathie ist eine Erkrankung, die sich im Rahmen von Stoffwechselentgleisungen entwickeln kann. Bekannt ist der Zusammenhang zwischen Diabetes mellitus und dem Auftreten der peripheren Neuropathie. Bislang gibt es nur wenige Studien, die den Zusammenhang zwischen der peripheren Neuropathie und anderen Stoffwechselsituationen untersuchten. Wir haben uns mit dem gleichzeitigen Auftreten der Adipositas, des MetS und der peripheren Neuropathie beschäftigt. Dabei wurde der Einfluss des Eisenstoffwechsels in diesem Zusammenhang genauer betrachtet.

In dieser Studie konnte am Mausmodell gezeigt werden, dass eine Degeneration der Nervenfasern an peripheren Nerven der Fußsohle und des Nervus ischiadicus durch Eisenmangel gefördert wird. Hingegen konnte ein durch exogene Eisenaufnahme entstandener erhöhter Eisengehalt diesen degenerativen Prozess verlangsamen. 
Unsere Untersuchungen konnten periphere Nervenschäden aufzeigen, wobei es vor allem zu einer Gewebsdegeneration distaler Axone kam. Vermutlich stellt die umgebende Entzündungsreaktion, die wir anhand der hohen Anzahl von Monozyten und autokriner Zytokine detektierten, einen ausschlaggebenden Faktor im Pathomechanismus der peripheren Neuropathie dar. TNF- $\alpha$ wird von den Entzündungszellen oder von Zellen im Fettgewebe sezerniert, die zu Veränderungen an der Blut-Nervenschranke führen. Dadurch kann es zu schädigenden Effekten im Nervengewebe kommen. Außerdem kann TNF- $\alpha$ als Entzündungsmediator weitere immunkompetente Zellen, wie Leukozyten, Makrophagen oder T- Zellen anlocken, die in das Endoneurium eindringen (Baum et al., 2016).

Es konnte festgestellt werden, dass die Ausschüttung proinflammatorischer Mediatoren an peripheren Nerven auch ohne gleichzeitigem Auftreten einer Hyperglykämie induziert wird.

Des Weiteren sahen wir, dass dieser Pathomechanismus durch freies Eisen beeinflusst werden kann. Bei den ob/ob-Mäusen, die eine Mangeleisendiät bekamen, konnte eine gesteigerte Anzahl proinflammatorischer Zellen, sowie eine vermehrte Expression des TNF- $\alpha$-Proteins nachgewiesen werden. Dieses Ergebnis lässt uns auf einen proinflammatorischen Einfluss durch Eisenmangel schließen. Ein genauer Zusammenhang dieses Effekts zwischen Eisenmangel und Adipositas bzw. MetS ist noch unklar.

Bemerkenswerterweise zeigen neueste Studien, dass Adipositas einen modulierenden Effekt auf den Eisengehalt von Adipozytenmakrophagen und der Ausschüttung von Gewebseisen hat (Orr et al., 2014).

Eine hochkalorische Diät erhöhte die absolute Makrophagenzahl im Fettgewebe. Dieser Anstieg konnte vor allem bei geringem Eisengehalt nachgewiesen werden. Eine verminderte Genexpression antiinflammatorischer Faktoren und eine verstärkte Expression proinflammatorischer Mediatoren konnte bei mangelndem Eisen aufgezeigt werden (Orr et al., 2014).

Ein gestörter Eisenstoffwechsel bei Makrophagen mit hohem Eisengehalt war mit einer Eisenüberladung in Adipozyten und einem Eisenmangel in der Leber verbunden. Mit zunehmender Eisenkonzentration wurden weniger entzündungsstimulierende Signale durch Makrophagen gesendet. Die Produktion und Sekretion proinflammatorischer Zytokine waren in Gegenwart von Eisen vermindert (Gan et al., 2017).

In der Pathologie der peripheren Neuropathie und der modulatorischen Rolle des Eisenstoffwechsels ließ sich kein Zusammenhang zum Blutglukosespiegel herstellen. In 
unserer Studie konnte auch ohne Vorliegen einer Hyperglykämie eine Inflammation an peripheren Nerven beobachtet werden.

Eine chronische Inflammation des Fettgewebes geht mit einer gestörten Signalübertragung des Insulinhaushaltes und einem kompromittierten Triglyzeridspeicher einher (O’Brien et al., 2017).

Wir konnten aufzeigen, dass der Funktionsverlust peripherer Nerven bei längeranhaltendem Eisenmangel ausgeprägter ist als bei einer Eisenüberladung.

Der Einfluss des Eisenstoffwechsels im peripheren Nervensystem ist noch relativ unklar und wenig beschrieben. Für uns ist es wichtig, die Rolle des Eisens im Entstehungsprozess der peripheren Neuropathie näher $\mathrm{zu}$ beleuchten, um adäquate Behandlungsstrategien beim Menschen entwickeln zu können. Um Langzeiteffekte aufzeigen zu können, waren 4 Monate des Experiments nicht ausreichend. Um jedoch Therapiestrategien zur Behandlung von Nervenschädigungen bzw. -entzündungen entwickeln zu können, wären Langzeituntersuchungen über die Wirkung des Eisenstoffwechsels auf Adipositas und MetS wichtig. 


\section{Literaturverzeichnis}

Agarwal AK, Yee (2019) Hepcidin. Advances in Chronic Kidney Disease 26(4): 298-305. doi: 10.1053/j.ackd.2019.04.005

Aguiar PCM, Coletta MVD, Silva de Souza JJ (2015) The association of dyslipidemia and peripheral diabetic neuropathy: the influence of urea. Diabetology and Metabolic Syndrome 7(Suppl 1): A30

Alberti KGMM, Zimmet P (2005) The metabolic syndrome- a new worldwide definition. The Lancet 366(9491): 1059-1062

Altamura S, Muckenthaler MU (2009) Iron toxicity in diseases of aging: Alzheimer's disease, Parkinson's disease and artherosclerosis. Journal of Alzheimer's disease 16(4): 879895

Avni T, Reich S, Lev N, Gafter-Gvili A (2019) Iron supplementation for restless legs syndrome - A systematic review and meta-analysis. European Journal of Internal Medicine. doi: 10.1016/j.ejim.2019.02.009

Baldereschi M, Inzitari M, Di Carlo A, Farchi G, Scafato E, Inzitari D (2007) Epidemiology of distal symmetrical neuropathies in the Italian elderly. Neurology 68(18): 1460-1467. doi: 10.1212/01.wnl.0000260606.36443.29

Bastard JP, Jardel C, Bruckert E, Blondy P, Capeau J, Laville M, Vidal H, Hainque B (2000) Elevated levels of interleukin 6 are reduced in serum and subcutaneous adipose tissue of obese woman after weight loss. Journal of Clinical Endocrinology and Metabolism 85 (9): $3338-3342$

Baum P, Kosacka J, Estrela-Lopis I, Woidt K, Serke H, Paeschke S, Stockinger M, Klöting N, Blüher M, Dorn M, Classen J, Thiery J, Bechmann I, Toyka KV, Nowicki M (2016) The role of nerve inflammation and exogenous iron load in experimental peripheral diabetic neuropathy (PDN). Metabolism 65(4): 391-405

Bekri S, Gual P, Anty R, Luciani N, Dahman M, Remesh B, Iannelli A, Staccini- myx A, Casanova D, Ben Amor I, Saint-Paul MC, Huet PM, Sadoul JL, Gugenheim J, Srai SKS, Tran A, Marchand- Brustel YL (2006) Increased adipose tissue expression of hepcidin in severe obesity is independent from diabetes and NASH. Gastroenterology 131(3): 788-796

Bergamini CM, Gambetti S, Dondi A, Cervellati C (2004) Oxygen, reactive oxygen species and tissue damage. Current Pharmaceutical Design 10(14):1611-26

Birkmeyer JD, Finks JF, O'Reilly, Oerline M, Carlin AM, Nunn AR, Dimick J, Banerjee M, Birkmeyer NJO, (2013) Surgical Skill and Complication Rates after Bariatric Surgery. The New England Journal of Medicine 369: 1434-1442. doi: 10.1056/NEJMsa1300625

Blaes F (2015) Diagnosis and therapeutic options for peripheral vasculitic neuropathy. Therapeutic Advances in Musculoskeletal Disease 7(2): 45-55. doi: $10.1177 / 1759720 \times 14566617$ 
Bonadonna RC, Cucinotta D, Fedele D, Riccardi G, Teingo A (2006) The metabolic syndrome is a risk indicator of microvascular and macrovascular complications in diabetes: results from Metascreen, a multicenter diabetes clinic- based survey. Diabetes Care 29 (12): $2701-2707$

Bonda DJ, Lee H, Blair JA, Zhu, X, Perry G, Smitha MA (2011) Role of Metal Dyshomeostasis in Alzheimer Disease. Metallomics 3(3): 267-270. doi: 10.1039/c0mt00074d

Bozzini C, Girelli D, Olivieri O, Martinelli N, Bassi A, De Matteis G, Tenuti I, Lotto V, Friso S, Pizzolo F, Corrocher R (2005) Prevalence of Body Iron Excess in the Metabolic Syndrome. Diabetes Care 28(8): 2061-2063. doi: https://doi.org/10.2337/diacare.28.8.2061

Callaghan B, Gao L, Li Y, Zhou X, Reynolds E, Banerjee M, Pop- Bosui R, Feldman EL, Ji L (2018) Diabetes and obesity are the main metabolic drivers of peripheral neuropathy. Annals of Clinical and Translational Neurology 5(4): 397-405

Callaghan B, Feldman E (2013) The metabolic syndrome and neuropathy: therapeutic challenges and opportunities. Annals of Neurology 74(3): 10.1002/ana.23986

Carrillo JLM, Del Campo JOM, Coronado OG, Gutiérrez PTV, Cordero JFC, Juárez JV (2018). Adipose Tissue and Inflammation, Adipose Tissue, Leszek Szablewski, IntechOpen. doi: 10.5772/intechopen.74227

Cepeda- Lopez AC, Melse- Boonstra A, Zimmermann MB, Herter-Aeberli I (2015) In overweight and obese women, dietary iron absorption is reduced and the enhancement of iron absorption by ascorbic acid is one-half that in normal-weight women. The American Journal of Clinical Nutrition 102(6): 1389-1397. doi: https://doi.org/10.3945/ajcn.114.099218

Chisholm DJ (1993) The diabetes control and complications trial (DCCT): a milestone in diabetes management. The Medical Journal of Australia 159: 721-723

Chiu PF, Ko SY, Chang CC (2012) Vitamin C affects the expression of hepcidin and erythropoietin receptor in HepG2 cells. Journal of Renal Nutrition 22(3): 373-376

Cortez M, Singleton JR, Smith AG (2014) Glucose intolerance, metabolic syndrome, and neuropathy. Handbook of Clinical Neurology 126: 109-122. doi: 10.1016/B978-0-444-534804.00009-6

Costa LA, Canani LH, Lisboa HRK, Tres GS, Gross JL (2004) Aggregation of features of the metabolic syndrome is associated with increased prevalence of chronic complications in type 2 diabetes. Diabetic Medicine 21(3): 252-255

Dă̆ ZÖ, Dilbaz B (2015) Impact of obesity on infertility in women. Journal of the TurkishGerman Gynecological Association 16(2): 111-117. doi: 10.5152/jtgga.2015.15232

Das SK, Wang W, Zhabyeyev P, Basu R, McLean B, Fan D, Dyck JR (2015) Iron-overload injury and cardiomyopathy in acquired and genetic models is attenuated by resveratrol therapy. Scientific Reports. doi : 10.1038/srep18132

DGAV (2019). doi: http://www.dgav.de/zertifizierung/zertifizierte-zentren/adipositas-undmetabolische-chirurgie.html 
Drel VR, Mashtalir N, Ilnytska O, Shin J, Li F, Lyzogubov VV, Obrosova IG (2006) The leptin- deficient (ob/ob) mouse: a new animal model of peripheral neuropathy of type 2 diabetes and obesity. Diabetes 55(12): 3335-3343

Feldman EL, Nave KA, Jensen TS, Bennett DL (2017) New horizons in diabetic neuropathy: mechanisms, bioenergetics, and pain. Neuron 93: 1296-313

Fenton HJH (1894) Oxidation of tartaric acid in presence of iron. Journal of the Chemical Society 65(65): 899-911

Gan ZS, Wang QQ, Li JH, Wang XL, Wang YZ, Du HH (2017) Iron Reduces M1 Macrophage Polarization in RAW264.7 Macrophages Associated with Inhibition of STAT1. Mediators of Inflammation: 8570818

Ganz T, Nemeth E (2006) Iron imports. IV. hepcidin and regulation of body iron metabolism. American Journal of Physiology- Gastrointestinal and Liver Physiology 290(2): 199-203

Haluzik M, Colombo C, Gavrilova O, Chua S, Wolf N, Chen M, Stannard B, Dietz KR, Le Roith D, Reitman ML (2004) Genetic backround (C57BL/6J versus FVB/N) strongly influences the severity of diabetes and insulin resistance in ob/ob mice. Endocrinology 145(7): 3258-3264

Hanefeld M, Leonhardt W (1981) Das metabolische Syndrom. Deutsches Gesundheitswesen 36: $545-551$

Hanewinckel R, Drenthen J, Ligthart S, Dehghan A, Franco OH, Hofman A, Ikram MA, van Doorn PA (2016) Metabolic syndrome is related to polyneuropathy and impaired peripheral nerve function: a prospective population- based cohort study. Journal of Neurology, Neurosurgery and Psychiatry 87(12):1336- 1342

Haschka D, Volani C, Stefani A, Tymoszuk P, Mitterling T, Holzknecht E, Heidbreder A, Coassin S, Sumbalova Z, Seifert M, Dichtl S, Theurl I, Gnaiger E, Kronenberg F, Frauscher B, Högl B, Weiss G (2019) Association of mitochondrial iron deficiency and dysfunction with idiopathic restless legs syndrome. Movement Disorders 34(1): 114-123

Herpertz S, Saller B (2001) Psychosomatische Aspekte der Adipositas. Psychotherapie Psychosomatik Medizinische Psychologie 51(9/10): 336-349. doi: 10.1055/s-2001-16901

Houstis N, Rosen ED, Lander ES (2006) Reactive oxygen species have a causal role in multiple forms of insulin resistance. Science 440(7086): 944-8

Huang J, Jones D, Luo B, Sanderson M, Soto J, Abel ED, Cooksey RC, McClain DA (2011) Iron overload and diabetes risk: a shift from glucose to fatty acid oxidation and increased hepatic glucose production in a mouse model of hereditary hemochromatosis. Diabetes 60(1): $80-87$

Hubler MJ, Peterson KR, Hasty AH (2015) Iron homeostasis: a new job for macrophages in adipose tissue? Trends in Endocrinology and Metabolism 26(2): 101-109 
Idriss HT, Naismith JH (2000) TNF $\alpha$ and the TNF receptor superfamily: Structure- function relationship(s). Microscopy Research \& Technique 50(3): 184-195

IFB- Adipositas (2019). doi: http://www.ifb-adipositas.de/

Imam MU, Zhang S, Ma J, Wang H, Wang F (2017) Review, Antioxidants Mediate Both Iron Homeostasis and Oxidative Stress. Nutrients 9(7). doi: 10.3390/nu9070671

Ismail- Beigi F, Craven T, Banerji MA, Basile J, Calles J, Cushman WC, Genuth S, Grimm RH Jr, Hamilton BP, Hoogwerf B, Karl D, Katz L, Krikorian A, O’Connor P, Pop-Busui R, Schubart U, Simmons D, Taylor H, Thomas A, Weiss D, Hramiak I (2010) Effect of intensive treatment of hyperglycaemia on microvascular outcomes in type 2 diabetes: an analysis of the ACCORD randomized trial. Lancet 376(9739): 419-430

Isomaa $\mathbf{B}^{\mathbf{1}}$, Lahti $\mathrm{K}$, Almpren $\mathrm{P}$, et al. (2001) Cardiovascular morbidity and mortality associated with the metabolic syndrome. Diabetes Care 24: 683-689

Isomaa $\mathbf{B}^{\mathbf{2}}$, Henricsson M, Almgren P, Toumi T, Taskinen MR, Groop L (2001) The metabolic syndrome influences the risk of chronic complications in patients with type II diabetes. Diabetologia 44(9): 1148-1154

IDF (2005) The IDF consensus worldwide definition of the metabolic syndrome. https://www.idf.org/our-activities/advocacy-awareness/resources-and-tools/60:idfconsensusworldwide-definitionof-the-metabolic-syndrome.html

Jin HJ, Park TS (2018) Role of inflammatory biomarkers in diabetic peripheral neuropathy. Journal of Diabetes Investigation 9(5): 1016-1018

Kamil K, Muhammad Dain Yazid MD, Idrus RBH, Das S, Kumar J (2019) Peripheral Demyelinating Diseases: From Biology to Translational Medicine. Frontiers in Neurology 10: 87. doi: 10.3389/fneur.2019.00087

Kawasaki N, Asada R, Saito A, Kanemoto S, Imaizumi K (2012) Obesity-induced endoplasmic reticulum stress causes chronic inflammation in adipose tissue. Scientific Reports. 2012; 2:799. doi: 10.1038/srep00799. Epub 2012 Nov 12.

Kellogg AP, Wiggin TD, Larkin DD, Hayes JM, Stevens MJ, Pop-Busui R (2007) Protective Effects of Cyclooxygenase-2 Gene Inactivation Against Peripheral Nerve Dysfunction and Intraepidermal Nerve Fiber Loss in Experimental Diabetes. Diabetes 56(12): 2997-3005

Kew MC (2014) Hepatic iron overload and hepatocellular carcinoma. Liver Cancer 3(1): 31 40

Kohgo Y, Ikuta K, Ohtake T, Torimoto Y, Kato J (2008) Body iron metabolism and pathophysiology of iron overload. International Journal of Hematology 88(1): 7-15

Kohen R, Nyska A (2002) Invited Review: Oxidation of Biological Systems: Oxidative Stress Phenomena, Antioxidants, Redox Reactions, and Methods for Their Quantification. Toxicologic Pathology 30(6):620-650. doi: 10.1080/01926230290166724 
Kohl B, Fische Sr, Groh J, Wessig C, Martini R (2010) MCP-1/CCL2 Modifies Axon Properties in a PMP22-Overexpressing Mouse Model for Charcot-Marie-Tooth 1A Neuropathy. The American Journal of Pathology 176(3): 1390-1399

Kompetenznetz- Adipositas. doi: https://www.kompetenznetz-adipositas.de

Krause A, Neitz S, Mägert HJ, Schulz A, Forssmann WG, Schulz-Knappe P, Adermann K (2000) LEAP-1, a novel highly disulfide-bonded human peptide, exhibits antimicrobial activity. FEBS Letters 480 (2-3): 147-150

Kulaksiz H, Theilig F, Bachmann S, Gehrke SG, Rost D, Janetzko A, Cetin Y, Stremmel W (2005) The iron-regulatory peptide hormone hepcidin: expression and cellular localization in the mammalian kidney. Journal of Endocrinology 184(2): 361-370. doi: https://doi.org/10.1677/joe.1.05729

Kulaksiz H, Fein E, Redecker P, Stremmel W, Adler G, Cetin Y (2008) Pancreatic beta-cells express hepcidin, an iron-uptake regulatory peptide. The Journal of Endocrinology 197(2): 241-249. doi: 10.1677/JOE-07-0528

Lakhal-Littleton S, Wolna M, Chung YJ, Christian HC, Heather LC, Brescia M, Ball V, Diaz R, Santos A, Biggs D, Clarke K, Davies B, Robbins PA (2016) An essential cellautonomous role for hepcidin in cardiac iron homeostasis. eLife (5). pii: e19804. doi: 10.7554/eLife.19804

Larson DS, Coyne DW (2013) Understanding and exploiting hepcidin as an indicator of anemia due to chronic kidney disease. Kidney Research and Clinical Practice 32(1): 11-15

Manoharan S, Gilles J. Guillemin GJ, Abiramasundari RS, Essa MM, Akbar M, Akbar MD (2016) The Role of Reactive Oxygen Species in the Pathogenesis of Alzheimer's Disease, Parkinson's Disease, and Huntington's Disease: A Mini Review. Oxidative Medicine and Cellular Longevity: 8590578. doi: 10.1155/2016/8590578

Marcovecchio ML (2017) Complications of Acute and Chronic Hyperglycemia. US Endocrinology 13(1): 17. doi: 10.17925/USE.2017.13.01.17

Martín-Aguilar L, Pascual-Goñi E, Querol (2019) Autoantibodies in immune-mediated inflammatory neuropathies. Medicina Clinica (Barcelona). pii: S0025-7753(19)30448-8. doi: 10.1016/j.medcli.2019.06.007

Martini R, Willison H (2016) Neuroinflammation in the peripheral nerve: Cause, modulator, or bystander in peripheral neuropathies? Glia 64(4): 475-486

Martyn CN, Hughes RA (1997) Epidemiology of peripheral neuropathy. Journal of Neurology Neurosurgery Psychiatry 62(4): 310-318

Mensink GBM, Schienkiewitz A, Haftenberger M, Lampert T, Ziese T, Scheidt- Nave C (2013) Übergewicht und Adipositas in Deutschland Ergebnisse der Studie zur Gesundheit Erwachsener in Deutschland (DEGS1). doi: 10.1007/ s00103-012-1656-3 
Merono T, Rosso LG, Sorroche P, Boero L, Arbelbide J, Brites F (2011) High risk of cardiovascular disease in iron overload patients. European Journal of Clinical Investigation 41(5): 479-486

Moayeri H, Bidad K, Zadhoush S, Gholami N, Anari S (2006) Increasing prevalence of iron deficiency in overweight and obese children and adolescents (Teheran Adolescent Obesity Study). European Journal of Pediatrics 165(11): 813-814

Mohammadi M, Gozashti MH, Aghadavood M, Mehdizadeh MR, Hayatbakhsh MM (2017) Clinical Significance of Serum IL-6 and TNF- $\alpha$ Levels in Patients with Metabolic Syndrome. Reports of Biochemistry \& Molecular Biology 6(1): 74-79

Monteiro R, Azevedo I (2010) Chronic inflammation in obesity and the metabolic syndrome. Mediators of Inflammation, pii: 289645. doi: 10.1155/2010/289645

Nuñez MT, Chana-Cuevas P (2018) New Perspectives in Iron Chelation Therapy for the Treatment of Neurodegenerative Diseases. Pharmaceuticals Basel 11(4): 109

O'Brien PD, Hinder LM, Callaghan BC, Feldman EL (2017) Neurological consequences of obesity. The Lancet. Neurology 16(6): 465-477

Orr JS, Kennedy A, Anderson-Baucum EK, Webb CD, Fordahl SC, Erikson KM, Zhang Y, Etzerodt A, Moestrup SK, Hasty1 AH (2014) Obesity Alters Adipose Tissue Macrophage Iron Content and Tissue Iron Distribution. Diabetes 63(2): 421-432

Oshiro S, Morioka MS, Kikuchi M (2011) Dysregulation of iron metabolism in Alzheimer's disease, Parkinson's disease, and amyotrophic lateral sclerosis. Advances Pharmalogical Sciences. doi: 10.1155/2011/378278

Ozcan U, Cao Q, Yilmaz E, Lee AH, Iwakoshi NN, Ozdelen E, Tunchman G, Gorgun C, Glimcher LH, Hotamisligil GS (2004) Endoplasmic reticulum stress links obesity, insulin action, and type 2 diabetes. Science 306(5695): 457-61

Paeschke S, Baum P, Toyka KV, Blüher M, Koj S, Klöting N, Bechmann I, Thiery J, Kosacka J, Nowicki M (2019) The Role of Iron and Nerve Inflammation in Diabetes Mellitus Type 2-Induced Peripheral Neuropathy. Neuroscience 406: 496-509. doi: 10.1016/j.neuroscience.2019.03.005

Pantopoulos K, Porwal SK, Tartakoff A, Devireddy L (2012) Mechanisms of mammalian iron homeostasis. Biochemistry 51(29): 5705-5724

Pareyson D, Saveri P, Pisciotta C (2017) New developments in Charcot-Marie-Tooth neuropathy and related diseases. Current Opinion in Neurology 30(5): 472-480. doi: 10.1097/WCO.0000000000000474

Petrides PE (2007) Spurenelemente. In: Löffler G, Petrides PE, Heinrich PC (eds) Biochemie und Pathobiochemie. Springer- Lehrbuch: 655-678. Springer, Berlin, Heidelberg. doi: https://doi.org/10.1007/978-3-540-32681-6

Pichler I, Del Greco MF, Gögele M, Lill CM, Bertram L, Do CB, Eriksson N, Foroud T, Myers RH, PD GWAS Consortium, Nalls M, Keller MF, International Parkinson's Disease 
Genomics Consortium, Wellcome Trust Case Control Consortium, Benyamin B, Whitfield JB, Genetics of Iron Status Consortium, Pramstaller PP, Hicks AA, Thompson JR, Minelli C (2013) Serum Iron Levels and the Risk of Parkinson Disease: A Mendelian Randomization Study. PLOS Medicine 10(6). doi: 10.1371/journal.pmed.1001462

Pop-Busui R, Lu J, Lopes N, Jones TLZ (2009) Prevalence of diabetic peripheral neuropathy and relation to glycemic control therapies at baseline in the BARI 2D cohort. Journal of the peripheral nervous system 14(1): 1-13

Salas RE, Gamaldo CE, Allen RP (2010) Update in restless legs syndrome. Current Opinion in Neurology 23(4): 401-406

Saltiel AR, Olefsky JM (2017) Inflammatory mechanisms linking obesity and metabolic disease. The Journal of Clinical Investigation 127(1): 1-4

Sarafidis PA, Rumjon A, MacLaughlin HL, Macdougall IC (2012) Obesity and iron deficiency in chronic kidney disease: the putative role of hepcidin. Nephrology Dialysis Transplantation 27(1): 50-57. doi: https://doi.org/10.1093/ndt/gfr686

Sattar N, Gaw A, Scherbakova O, Ford I, O'Reilly DS, Haffner SM, Isles C, Macfarlane PW, Packard CJ, Cobbe SM, Shepherd J (2003) Metabolic syndrome with and without C- reactive protein as a predictor of coronary heart disease and diabetes in the West of Scotland Coronary Prevention Study. Circulation 108(4): 414-419

Sena LA, Chandel NS (2012) Physiological roles of mitochondrial reactive oxygen species. Molecular Cell 48(2): 158- 167

Shim YS, Kang MJ, MD, Oh YJ, Baek JW, Yang S, Hwang IT (2017) Association of serum ferritin with insulin resistance, abdominal obesity, and metabolic syndrome in Korean adolescent and adults. Medicine (Baltimore) 96(8): e6179. doi: 10.1097/MD.0000000000006179

Sommer C, Geber C, Young P, Forst R, Birklein F, Schoser B (2018) polyneuropathiesetiology, diagnosis, and treatment options. Deutsches Ärzteblatt 115(6): 83-90

Srikanthan K, Feyh A, Visweshwar H, Shapiro JI, Sodhi K (2016) Systematic Review of Metabolic Syndrome Biomarkers: A Panel for Early Detection, Management, and Risk Stratification in the West Virginian Population. International Journal of Medical Sciences 13(1): $25-38$

Stafeev IS, Menshikov MY, Tsokolaeva ZI, Shestakova MV, Parfyonova YV (2015) Molecular Mechanisms of Latent Inflammation in Metabolic Syndrome. Possible Role of Sirtuins and Peroxisome Proliferator-Activated Receptor Type $\gamma$. Biochemistry 80(10): 12171226

Stino AM, Smith AG (2017) Peripheral neuropathy in prediabetes and the metabolic syndrome. Journal of Diabetes Investigation 8(5): 646-655 
Szmitko PE, Verma S, (2007) C-Reactive Protein and the Metabolic Syndrome: Useful Addition to the Cardiovascular Risk Profile? Journal of the CardioMetabolic Syndrome 1(1): 66-69

Trayhurn P, Wood IS (2004) Adipokines: inflammation and the pleiotropic role of white adipose tissue. British Jornal of Nutrition 92(3): 437-455

Victor M, Savina H, Julia P, Vasil V, Maria P, et al. (2017) The Role of Iron Homeostasis in Alzheimer's Disease. Journal Alzheimers Neurodegeneration 3 (1): 11

Vinik AI, Bril V, Kempler P, Litchy WJ, Tesfaye S, Price KL, BastyrIII EJ, the MBBQ Study Group (2005) Treatment of symptomatic diabetic peripheral neuropathy with the protein kinase $C \beta$-inhibitor ruboxistaurin mesylate during a 1-year, randomized, placebo-controlled, double-blind clinical trial Author links open overlay panel. Clinical Therapeutics 27(8): 11641180

Wang JY, Zhuang QQ, Zhu LB, Zhu H, Li T, Rui Li, Chen SF, Chen-Ping Huang CP, Zhang $\mathrm{X}$, Zhu JH (2016) Meta-analysis of brain iron levels of Parkinson's disease patients determined by postmortem and MRI measurements. Scientific Reports 6: 36669. doi: $10.1038 /$ srep36669

Ward RJ, Zucca FA, Duyn JH, Crichton RR, Zecca L (2014) The role of iron in brain ageing and neurodegenerative disorders. Lancet Neurology 13(10): 1045-1060

Warner MJ, Kamran MT (2018) Anemia, Iron Deficiency. StatPearls [Internet]. Treasure Island (FL): Pearls Publishing; 2019. doi: https://www.ncbi.nlm.nih.gov/books/NBK448065/

White FA, Jung H, Miller RJ (2007) Chemokines and the pathophysiology of neuropathic pain. PNAS 104(51): 20151-20158

Wiggin TD, Sullivan KA, Pop- Busui R, Amato A, Sima AAF, Feldman EL (2009) Elevated triglycerides correlate with progressions of diabetic neuropathy. Diabetes 58(7): 1634-1640

Wisse BE (2004) The Inflammatory Syndrome: The Role o+f Adipose Tissue Cytokines in Metabolic Disorders Linked to Obesity. Journal of the American Society of Nephrology 15 (11): 2792-2800

WHO (2000) Obesity: preventing and managing the global epidemic. WHO Technical Report Series 894, Genf 2000

WHO (2017) Global Health Observatory data repository. WHO (2017). doi: http://apps.who.int/gho/data/node.main.A896?lang=en

Yanoff LB, Menzie CM, Denkinger B, Sebring NG, McHugh T, Remaley AT, Yanovski JA (2007) Inflammation and iron deficiency in the hypoferremia of obesity. International Journal of Obesity 31(9): 1412-1419

Yuki N (2015) Molecular Mimicry and Guillain-Barré Syndrome. Brain and Nerve 67(11): 1341-1346. doi: 10.11477/mf.1416200304 
Zafon C, Lecube A, Simó R (2010) Iron in obesity. An ancient micronutrient for a modern disease. Obesity Reviews 11(4): 322-328

Zhang Y, Proenca R, Maffei M, Barone M, Leopold L, Friedman JM (1994) Positional cloning of the mouse obese gene and its human homologue. Nature 372(6505): 425-32

\section{Anhang}

\subsection{Tabellenverzeichnis}

Tab. 1: Vergleich der Serumkonzentrationen von IL-6, TNF- $\alpha$ und CRP adipöser diabetischer, adipöser nichtdiabetischer und gesunder Frauen

Tab. 2: Liste der verwendeten Antikörper mit Verdünnung und Hersteller

\subsection{Abbildungsverzeichnis}

Abb. 1: Schematische Darstellung der Wirkung von Hepcidin auf den Eisenstoffwechsel 


\section{Darstellung des eigenen Beitrags}

Hiermit erkläre ich, dass die u. g. Spezifizierungen des eigenen Beitrags an der vorliegenden Arbeit der Wahrheit entsprechen. Folgende Punkte wurden eigenständig beigetragen.

- Elektrophysiologie: Messung und Auswertung der Nervenleitgeschwindigkeit (25\%)

- Entnahme und Vorbereitung der Gewebs- und Blutproben (50\%)

- Immunhistochemische Färbung mit Auswertung (50 \%)

- Aufnahme der elektronenmikroskopischen Bilder und Auswertung (100 \%)

- Western Blot: Probenvorbereitung, Durchführung und Auswertung (50\%)

- Recherche

- Manuskript-Anfertigung (50\%)

Folgende Personen bestätigen die Richtigkeit meiner Spezifizierung des eigenen Beitrags:

Korrespondierender Autor: PD Dr. Marcin Nowicki

Gleichberechtigter Erstautor: Dr. habil. Joanna Kosacka

Ko- Autor: Prof. Dr. med. Klaus Viktor Toyka

Ko- Autor: M.Sc. Sabine Paeschke

Gleichberechtigter Seniorautor: PD Dr. med. Petra Baum 


\section{Erklärung über die eigenständige Abfassung der Arbeit}

Hiermit erkläre ich, dass ich die vorliegende Arbeit selbständig und ohne unzulässige Hilfe oder Benutzung anderer als der angegebenen Hilfsmittel angefertigt habe. Ich versichere, dass Dritte von mir weder unmittelbar noch mittelbar eine Vergütung oder geldwerte Leistungen für Arbeiten erhalten haben, die im Zusammenhang mit dem Inhalt der vorgelegten Dissertation stehen und dass die vorgelegte Arbeit weder im Inland noch im Ausland in gleicher oder ähnlicher Form einer anderen Prüfungsbehörde zum Zweck einer Promotion oder eines anderen Prüfungsverfahrens vorgelegt wurde. Alles aus anderen Quellen und von anderen Personen übernommene Material, das in der Arbeit verwendet wurde oder auf das direkt Bezug genommen wird, wurde als solches kenntlich gemacht. Insbesondere wurden alle Personen genannt, die direkt an der Entstehung der vorliegenden Arbeit beteiligt waren. Die aktuellen gesetzlichen Vorgaben in Bezug auf die Zulassung der klinischen Studien, die Bestimmungen des Tierschutzgesetzes, die Bestimmungen des Gentechnikgesetzes und die allgemeinen Datenschutzbestimmungen wurden eingehalten. Ich versichere, dass ich die Regelungen der Satzung der Universität Leipzig zur Sicherung guter wissenschaftlicher Praxis kenne und eingehalten habe. 


\section{Lebenslauf}

Persönliche Angaben

$\begin{array}{ll}\text { geboren am } & 01.04 .1986 \text { in Görlitz } \\ \text { Nationalität } & \text { deutsch } \\ \text { Familienstand } & \text { ledig }\end{array}$

Arbeitsanschrift

Helios Klinikum Schkeuditz

Leipziger Straße 45

04435 Schkeuditz

Tel.: 034204/800

E- Mail: katrin.woidt@helios-kliniken.de

Tätigkeit Assistenzärztin

Beruflicher Werdegang

Seit Januar 2017

Seit 2012

Seit 2010

2004- 2007

2007

2007- 2008

2008- 2009

2010
Assistenzärztin für Unfallchirurgie und Orthopädie, Helios Klinikum Schkeuditz, Deutschland

Doktorandin am Institut für Anatomie, Medizinische Fakultät der Universität Leipzig, Deutschland Fachgebiet: periphere Nerven

Studium der Humanmedizin, Universität Leipzig, Deutschland

Ausbildung zur Arzthelferin, Gastroenterologie Praxis Dr.med. Wiechmann, Potsdam, Deutschland Arzthelferin, Chirurgie, Praxis Dres. Hirsemann/Wilke/Rudtke, Potsdam, Deutschland Arzthelferin, Chirurgie, Dres. Lichowos, Berlin, Deutschland

Arzthelferin, MVZ Orthopädie/Allgemeinmedizin/ Physikalisch Rehabilitative Medizin, Dres. Mälzer, Berlin, Deutschland Arzthelferin, Chirurgie, MVZ Polikum Friedenau, Berlin, Deutschland 


\section{Publikationen}

1. Baum P, Kosacka J, Estrela- Lopis I, Woidt K, Serke H, Paeschke S, Stockinger M, Klöting N, Blüher M, Dorn M, Classen J, Thiery J, Bechmann I, Toyka KV, Nowicki M (2016) The role of nerve inflammation and exogenous iron load in experimental peripheral diabetic neuropathy. Metabolism 65(4): 391- 405

2. Kosacka J, Woidt K*, Toyka KV, Paeschke S, Klöting N, Bechmann I, Blüher M, Thiery J, Ossmann S, Baum P, Nowicki M (2019) The role of dietary non-heme iron load and peripheral nerve inflammation in the development of peripheral neuropathy $(\mathrm{PN})$ in obese non-diabetic leptin-deficient $o b / o b$ mice. Neurol Res. 41(4): 341-353*-gleichberechtigte Erstautorenschaft 


\section{Danksagung}

Ich bedanke mich bei Herrn Prof. Dr. med. Ingo Bechmann für die Realisierung meiner Doktorarbeit. Außerdem möchte ich mich herzlichst bei PD Dr. Marcin Nowicki und Dr. habil. Joanna Kosacka bedanken, die mich auf dem Weg zu meinem lang ersehnten Ziel begleiteten und mit Rat und Tat zur Seite standen. Ich möchte mich bei meinen Eltern bedanken, die immer an mich geglaubt und mich stets unterstützt haben. Vielen Dank an Dr. med. Johannes Kohlmann und Dr. med. Wolfgang Wrabetz für ihre konstruktiven Einflüsse. Ein besonderer Dank gilt meinem Verlobten, der immer hinter mir stand. 